\title{
MAPEAMENTO E CARACTERIZAÇÃO GEOMORFOLÓGICA: Ecorregião Raso da Catarina e Entorno NE da Bahia
}

\author{
Prof. Msc. João Henrique Moura Oliveira \\ Curso de Geografia DCHF-UEFS \\ Av. Transnordestina, S/N Novo Horizonte CEP: 44.036.900 Feira de Santana (BA), Brasil \\ Tel. (+55 75) 32248215 -jmouraoliveira8@gmail.com \\ Prof ${ }^{\mathrm{a}}$. Dr ${ }^{\mathrm{a}}$. Joselisa Maria Chaves \\ joselisamaria@gmail.com
}

\begin{abstract}
RESUMO
Este artigo objetivou elaborar caracterização e mapeamento geomorfológico sistemático de parte da Ecorregião Raso da Catarina-BA e entorno utilizando metodologias de mapeamento geomorfológico consagradas em âmbito nacional (ROSS, 1990 e 1992), apoiado técnico-metodológicamente nas geotecnologias (SR e SIG). Como material principal para realização do mapeamento utilizou-se dados obtidos por Sensoriamento Remoto como o Modelo Digital de Elevação - MDE do Programa SRTM/ NASA resolução 90 m. A resolução do MDE foi refinada para 30 m utilizando a krigagem, a partir desse gerou-se mapas de Declividade, Hipsometrico e Relevo Sombreado (produtos auxiliares para caracterização e mapeamento). Seguiu-se os pressupostos metodológicos de Ross (1992), chegando a caracterizar até $4^{\circ}$ táxon, propondo mapeamento na escala 1:100.000. O $3^{\circ}$ e $4^{\circ}$ táxon foi compartimentado por vetorização em tela e identificado pela determinação dos índices de dissecação do relevo através da elaboração de perfis topográficos automaticamente e interativos em software de SIG, foi percebido a eficácia e praticidade desse procedimento. Ficou evidenciada a possibilidade de aplicabilidade das geotecnologias aliada a metodologias consagrada de mapeamento geomorfológico.
\end{abstract}

Palavras-chave: Geomorfologia-NE do Brasil, metodologias-mapeamento geomorfológico, modelagem digital de terreno.

\begin{abstract}
This paper aimed to develop a systematic geomorphological mapping and characterization of part of the ecoregion Raso da Catarina, Bahia and environs using geomorphological mapping methodologies enshrined in national (ROSS, 1990 and 1992), supported by technical and methodological in geomatics (remote sensing and geographical information system). As the main material used to map the data were obtained by remote sensing as the Digital Elevation Model DEM Program SRTM / NASA resolution $90 \mathrm{~m}$. The resolution of the DEM were refined to $30 \mathrm{~m}$ using kriging, since that was generated by maps of slope, hipsometric and Shaded Relief (auxiliary products for characterization and mapping). This was followed by the methodological assumptions of Ross (1992), reaching up to 4rd characterize taxon proposing mapping on the scale 1:100,000. The 3rd and 4th taxon was foreclosed by tracing on screen and identified by determining the rate of dissection of relief through the preparation of topographic profiles automatically and interactive GIS software, was the perceived effectiveness and practicality of this procedure. This disclosed the possibility of applicability of Geomatic allied methodologies devoted to geomorphological mapping.
\end{abstract}

Key words: Geomorphology-Northeast Brazil, Methodologies- geomorphological mapping, Digital Terrain Modeling.

\section{RESUMEN}

Este artículo tiene la finalidad de desarrollar un mapeo sistemático geomorfológico y caracterización de una parte de la ecorregión del Raso da Catarina, Bahía y sus alrededores utilizando metodologías geomorfológico mapeo consagrado en el nacional (ROSS, 1990 y 1992), con el apoyo técnico y metodológico en teledeccion. A medida que el material principal utilizado para mapear los datos fueron obtenidos por sensores remotos como el Modelo Digital de Elevación - DEM Programa SRTM/NASA resolución $90 \mathrm{~m}$. La resolución del DEM se perfeccionaron hasta $30 \mathrm{~m}$ utilizando kriging, ya que se generó por los mapas de la pendiente, y hipsomètric Relieve Sombreado (productos auxiliares para la caracterización y cartografía). Esto fue seguido por los presupuestos metodológicos de Ross (1992), alcanzando un máximo de 4 caracterizan taxón proponer la cartografía a escala 1:100.000. El taxón 3 y 4 se encontraba limitado por la localización en la pantalla y se identifica mediante la determinación del tipo de disección de alivio a través de la preparación de perfiles topográficos de forma automática e interactiva de software GIS, fue la percepción de su eficacia y la viabilidad de este procedimiento.

Palabras clave: Geomorfología, NE de Brasil, metodologías, cartografía geomorfológica, Modelado Digital del Terreno.

\section{INTRODUÇÃO}

A procura do conhecimento espacial do ambiente remonta aos primórdios da humanidade. Esta busca perpassou diretamente a representação do conhecido e do que estava susceptível de apropriação e exploração. A partir da construção de técnicas e desenvolvimento da arte de conceber 
e abstrair os fenômenos do meio ambiente em analogias à realidade, o ser humano pôde utilizar mais eficazmente os recursos para seu próprio interesse. Segundo Argento (2001), primeiramente, era necessário: a) conhecer onde, no espaço, se localizavam os fenômenos; b) como esses mesmos fenômenos se distribuíam no espaço; e c) por que ocorriam daquela forma.

Contudo, o conhecimento acumulado, no decorrer do tempo, aliado à despreocupação em desenvolver uma melhor racionalidade no uso dos recursos ambientais, acarretou uma urgência em minimizar seu uso indiscriminado. Argento (2001) acrescentou que a preocupação está direcionada na compreensão dos fenômenos na prevenção de soluções que levam à manutenção de um equilíbrio de estado contínuo.

Atualmente, a preocupação se volta ao entendimento de como os fenômenos ambientais atuam e atuarão, ou como se estabelece a complexidade inerente a tais fenômenos. Torna-se necessária a elaboração de estudos que busquem diagnosticá-los, compreendendo o comportamento e respostas das variáveis ambientais envolvidas nos fenômenos, além de propor prognósticos.

Nesse sentido, a geomorfologia insere-se como componente da ciência geográfica com uma contribuição potencial no que se refere à elucidação de fenômenos ambientais, no subsídio ao desenvolvimento desses estudos e, conseqüentemente, com uma compreensão integrada da paisagem. Os estudos geomorfológicos possuem grande relevância no escopo das geociências, pois estão relacionados à caracterização do ambiente, procurando descrever e diagnosticar as formas de relevo, a partir da identificação e compreensão dos processos morfogenéticos. A partir desses estudos, é possível entender as condições gerais da dinâmica da paisagem. Esse entendimento contribui para o desenvolvimento de prognósticos e interpretações das condições ambientais (ROSS, 1990 e 2006).

Destarte, os estudos geomorfológicos são melhores consubstanciados pela representação cartográfica dos fatos geomorfológicos, ou seja, é mais bem apreendido e abstraído pela espacialização das formas de relevo e suas relações com estrutura e processos, bem como com a própria dinâmica dos processos, considerando suas particularidades (CASSETI, 2006).

Neste sentido, o mapeamento geomorfológico tem por função primordial apresentar a base e a síntese da pesquisa geomorfológica e não o resultado em si do estudo. Para Tricart (1965), segundo Ross (1990), o mapeamento geomorfológico "constitui a base da pesquisa e não a concretização gráfica de pesquisa já feita". Assim, o essencial do mapeamento geomorfológico é apresentar, de forma sintética elucidativa, as características e atributos relacionados à gênese, forma e cronologia do relevo.

Assim, o objetivo desse artigo é elaborar um mapeamento geomorfológico sistemático de parte da Ecorregião Raso da Catarina - BA e entorno utilizando metodologias de mapeamentos geomorfológicas consagradas em âmbito nacional (ROSS, 1990 e 1992), tendo como âncora técnico-metodológica as geotecnologias (SR e SIG).

\section{ÁREA DE ESTUDO}

A porção territorial da Ecorregião Raso da Catariana estudada situa-se na região econômica Nordeste do Estado da Bahia, delimitada entre as coordenadas 9 $9^{\circ}$ '28' a 10 1'26.30" de latitude Sul e $38^{\circ} 11^{\prime} 11^{\prime \prime}$ a $39^{\circ} 0$ ' $22^{\prime \prime}$ de longitude Oeste, compreendendo partes do município de Paulo Afonso, Rodelas, Glória, Jeremoabo e pequena parte dos municípios de Chorrochó e Canudos. Do ponto de vista da superfície, há um espaço ocupando, aproximadamente, $8.720 \mathrm{Km} 2$ (Figura 1).

O Raso da Catarina está inserido em um setor do Semi-árido brasileiro, com déficit hídrico muito acentuado e precipitações médias anuais irrisórias, de menos $400 \mathrm{~mm}$ até no máximo $650 \mathrm{~mm}$ (SEI, 1999), o que acarreta uma extrema rusticidade de suas caatingas e da paisagem de um modo geral, e uma consequente atenção de âmbito ambiental (AB'SABER, 2006). A área de estudo está inserida em duas Bacias Hidrográficas: as partes, central e norte encontram-se inseridas na Bacia do Baixo-médio São Francisco e a porção sul, na Bacia do rio Vaza-Barris. O rio São Francisco faz limite nordeste da área de estudo, sendo compreendida pelos lagos das Usinas Hidrelétricas 
de Itaparica mais a norte, e do Complexo de Paulo Afonso a jusante da área de estudo. A rede de drenagem tributária é composta essencialmente por cursos intermitentes e por vezes efêmeros.

Aliados a esse fato, na área, encontram-se as seguintes Unidades de Conservação: i) uma Área de Proteção Ambiental Estadual (APA Serra Branca/ Raso da Catarina); ii) uma Estação Ecológica (ESEC Raso da Cataria) e iii) uma Área de Relevante Interesse Ecológico (ARIE Cocorobó), sendo essas duas últimas administradas pelo IBAMA. Além, de quatro Terras Indígenas (Pankararé, Brejo dos Burgos, Quixaba e Kantaruré).

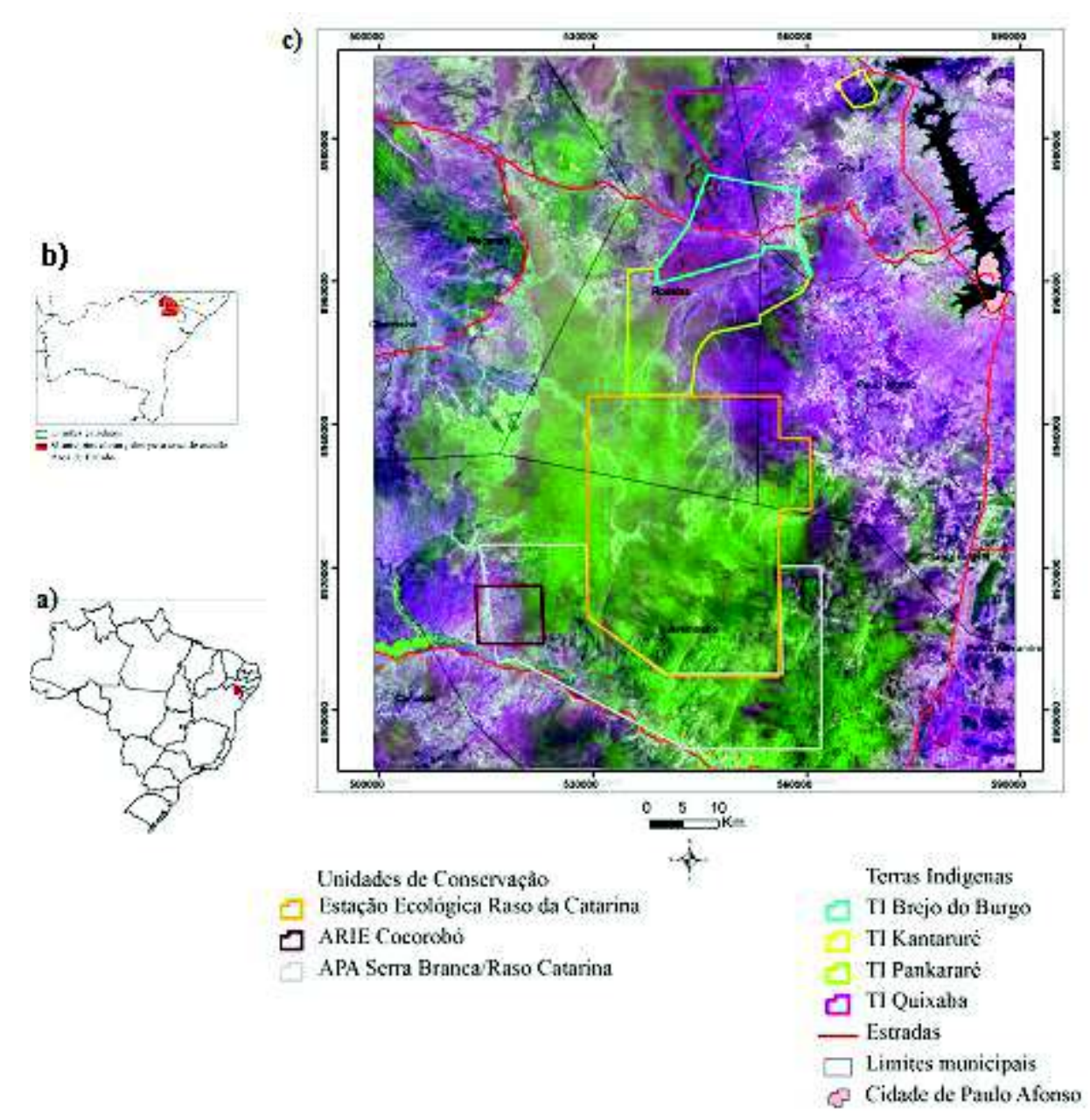

Figura 1 - Localização da área pesquisada: Brasil (a); Bahia, municípios e área de estudo( b) e Imagem Landsat 7 ETM+, Composição Colorida 5R4G3B, destacando as Unidades de Conservação e as Terras Indígenas (c)

Segundo o Texto Explicativo do Mapa Geológico do Estado da Bahia (BARBOSA E DOMINGUES, 1996). A predominância litológica refere-se a rochas das Formações sedimentares do Cretáceo, representadas, na área, pelas Formações Santana, Marizal, Poço Verde, São Sebastião, Candeias, Santo Amaro e o Grupo Ilhas. O período Jurássico é caracterizado, na coluna estratigráfica, por rochas do Grupo Brotas, representadas, na área, pelas Formações Aliança e Sergi. Na seqüência, tem-se a Formação Santa Brígida, do Permiano, e a Formação Tacaratu, do Ordoviciano/ Siluriano. Estas representam depósitos da Região de Paulo Afonso - Santa Brígida, ocorrendo ao longo da borda oriental da Bacia de Tucano Norte e em exposições isoladas sobre o embasamento adjacente à mesma. Em subsuperfície, essas Formações aparecem compondo a seção basal da Bacia de Tucano Norte.

No contexto da geomorfologia regional a área de estudo está inserida em três Unidades Morfoestruturais segundo A classificação taxonômica do relevo de Ross (1992) ou em três Domínios Morfoestruturais na classificação do Projeto RADAMBRASIL (BRASIL, 1983; NUNES, 1995): 
1- Bacias e Coberturas Sedimentares Inconsolidadas (Bacia de Tucano Norte); é representada pela Unidade Morfoescultural, intermediária, denominada de Planalto da Bacia Tucano-Jatobá, esta se subdivide na Unidade Morfológica designada Chapadas do Raso da Catarina.

2- Remanescentes das raízes de Dobramentos (Faixa de Dobramentos e Coberturas Metassedimentares Associadas); é representada pela Unidade Morfoescultural, intermediária, dos Baixos Planaltos Marginais à Bacia de Tucano-Jatobá (Baixos Planaltos Sertanejos), subdividindo-se na Unidade Morfológica do Tabuleiro Dissecado do Vaza-Barris (Baixo Planalto do Vaza-Barris - Macururé).

3- Maciços Remobilizados (Embasamentos em Estilos Complexos) - são subdivididas em duas Unidades Morfoesculturais; o Baixo Planalto Pré-litorâneo (Baixo Planalto do São Francisco) e as Depressões Interplanálticas. Essas, por suas vez, são representadas pelas Unidades Morfológicas do Pediplano do Baixo São Francisco e o Pediplano Sertanejo, respectivamente.

\section{MODELOS DIGITAIS DE ELEVAÇÃO E SUA APLICAÇÃO EM GEOMORFOLOGIA}

A elaboração de Modelos Digitais de Elevação (MDE) pode ser realizada de várias maneiras: a partir de pontos amostrais no terreno com atributos xyz, sendo x e y as coordenadas e $\mathrm{z}$ a altimetria; digitalização de folhas topográficas analógicas, ou pontos cotados. Nestes casos, para criação da superfície contínua (MDE), utilizam-se, por exemplo, métodos de interpolação como a krigagem e o inverso do quadrado da distância (BURROUGH e MCDONNELL 1998; VALERIANO, 2002 e SILVA, 2003); ou ainda, como demonstrou Barros (2006), a partir de pares estereoscópicos de imagens ópticas como as dos sensores ASTER, SPOT e IKONOS ou por Interferometria de mosaicos de Radar como do RADAR-SAT e SRTM-NASA.

O MDE utilizado na pesquisa foi proveniente do Projeto SRTM-NASA (SHUTLE-SRTM-NASA, 2001). A partir do desenvolvimento deste projeto, ocorreu um grande impulso em estudos geomorfológicos utilizando o aparato técnico-metodológico das geotecnologias envolvendo Modelos Digitais de Elevação, principalmente, devido à facilidade de aquisição desses dados, pois é disponibilizada gratuitamente pela rede mundial de computadores (internet), além da implementação de algoritmos de tratamento e manipulação desses MDE's em softwares de PDI e SIG.

Esses softwares disponibilizam ferramentas de derivação de dados morfométricos, ou seja, permitem a implementação de comandos por algoritmos específicos com a mesma função. Podem ser extraídos parâmetros morfométricos como declividade (VALERIANO, 2003c), curvatura vertical (VALERIANO, 2003b), curvatura horizontal (VALERIANO e CARVALHO-JÚNIOR, 2003), cálculo de área de contribuição (RAMOS et al. 2003) e derivação de mapas temáticos como hipsométricos e de aspecto do relevo ou exposição de vertentes (ARAÚJO, 2004), além da extração de parâmetros hidrológicos como drenagem (VALERIANO e MORAES, 1996) e delimitação de bacias hidrográficas (LOBÃO e VALE, 2007).

Valeriano (2004) analisou e testou o MDE-SRTM com dados originais disponibilizados com $90 \mathrm{~m}$ de resolução espacial (a rigor 3 arcos de segundo ou $0,000833^{\circ}$ ). Ele considerou a necessidade de operações de pré-processamento para adequada aplicação desse MDE em estimativas e mapeamentos de variáveis morfométricas. Visto isso, o autor propôs, então, uma metodologia de refinamento do MDE, ou seja, a partir da krigagem, os dados originais são interpolados obtendo uma resolução de $30 \mathrm{~m}$ (a rigor, em coordenadas geográficas, como 1 arco segundo, 1 ” ou 0,000278 ), permitindo assim a sua utilização em escalas relativamente detalhadas.

Oguchi (2006), citado por Valeriano (2007), afirmou que, apesar dos contínuos avanços da modelagem do relevo com geoprocessamento, um dos principais problemas observados é a fraca inserção do conhecimento acumulado a partir da geomorfologia convencional em trabalhos de SIG. Ele recomenda uma maior colaboração entre especialistas de SIG e intérpretes tradicionais. 
Assim, Valeriano (2007) apontou a necessidade de técnicas adequadas de representações topográficas em SIG, representações estas provenientes de MDT ou MDE e afirmou que a ausência das técnicas de representação de variáveis topográficas derivadas impede que as vantagens de análise digital sejam, efetivamente, aproveitadas na interpretação do relevo. Isso significa que a falta de técnicas de representação de variáveis impede a utilização de métodos já consagrados na interpretação geomorfológica, pois não se consegue extrair digitalmente ou automaticamente toda informação morfométricas que pode ser derivada dos MDTs, restringindo a potencialidade da interpretação geomorfológica. Procurando sanar, em parte, esta lacuna, Valeriano (op. cit.) propôs a adaptação de recursos típicos de tratamento de imagens multi-espectrais para o desenvolvimento de técnicas de análise geomorfológica.

\section{MATERIAIS E MÉTODOS}

A organização, edição e sistematização dos dados utilizados na elaboração de uma pesquisa se constituem em uma etapa de substancial importância, pois é quando se constata a veracidade, viabilidade e aplicabilidade dos dados a serem utilizados, sejam eles dados primários ou secundários (SILVA, 2003). Nesta pesquisa os dados arquitetados em ambiente SIG com o propósito final de se realizar a caracterização e mapeamento geomorfológico da área estudada foram os seguintes:

1) Dados cartográficos digitais pré-existentes - Folhas topográficas Canché, Salgado do Melão, Santa Brígida e Paulo Afonso escala 1:100. 000: (SEI, 2001), Mapa de Geologia digital do Estado da Bahia (CPRM, 2003); Mapa de Solo do Estado da Bahia digital (SRH, 2001), Mapa de Cobertura Vegetal e Uso do Solo (DDF/ SEAGRI, 1998);

2) Dados Planimétricos - Vetores das Terras Indígenas (BRASIL, 1985 e LOBÃO, 2003 e IBAMA, 2007), arquivo vetorial das Unidades de Conservação Federal (IBAMA, 2007), e dos Municípios abrangidos pela área de estudo (IBGE, 2007), dados planimétricos provenientes das folhas topográficas, como rede hidrográficas isolinhas hipsométricas;

3) Dados obtidos por meio de Sensoriamento Remoto - Modelo Digital de Elevação do Programa SRTM/ NASA (2001) resolução 90 m, Imagens digitais do sensor ETM+, satélite LANDSAT 7, cenas 216/66 e 216/67 de 31-10-2001 e 12-01-2003;

4) Dados de GPS - trabalho de campo na área de estudo.

Os mapas temáticos foram gerados a partir do MDE refinado para $30 \mathrm{~m}$ (Figura 2) pelo método geoestatístico da krigagem (VALERIANO, 2004). Com este método, derivou-se em ambiente SIG a Imagem do Relevo Sombreado (Shaded Relief), os mapas: Hipsométrico, Declividade, Aspecto (Exposição de Vertentes) de Curvatura Horizontal e de Curvatura Vertical (Figura 3).

As características fisiográficas observadas na discriminação das unidades geomorfológicas foram relacionadas à rugosidade topográfica, declividades dominantes, forma dos topos e encostas, morfocronologia, aspectos morfométricos, interação com os outros componentes do potencial ecológico (geologia, pedologia e solos) e da exploração biológica (cobertura vegetal), além de uso antrópico (ROSS, 1990; FREITAS, 2006).

A compartimentação geomorfológica proposta procurou subsidiar o entendimento de maneira integrada a Paisagem de uma porção da ecorregião do Raso da Catarina e entorno, adotando o relevo como entidade primordial, como foi defendido por Falcão-Sobrinho (2006):

Sugerimos ter o relevo como ponto de partida ao entendimento da Paisagem não correndo o risco de dizer que o relevo seria o ponto de partida antes mesmo de se perceber a Paisagem como um todo, mas que contribuiria para dimensionar a paisagem para fins analíticos e não, apenas como unidade elementar (p.76). 


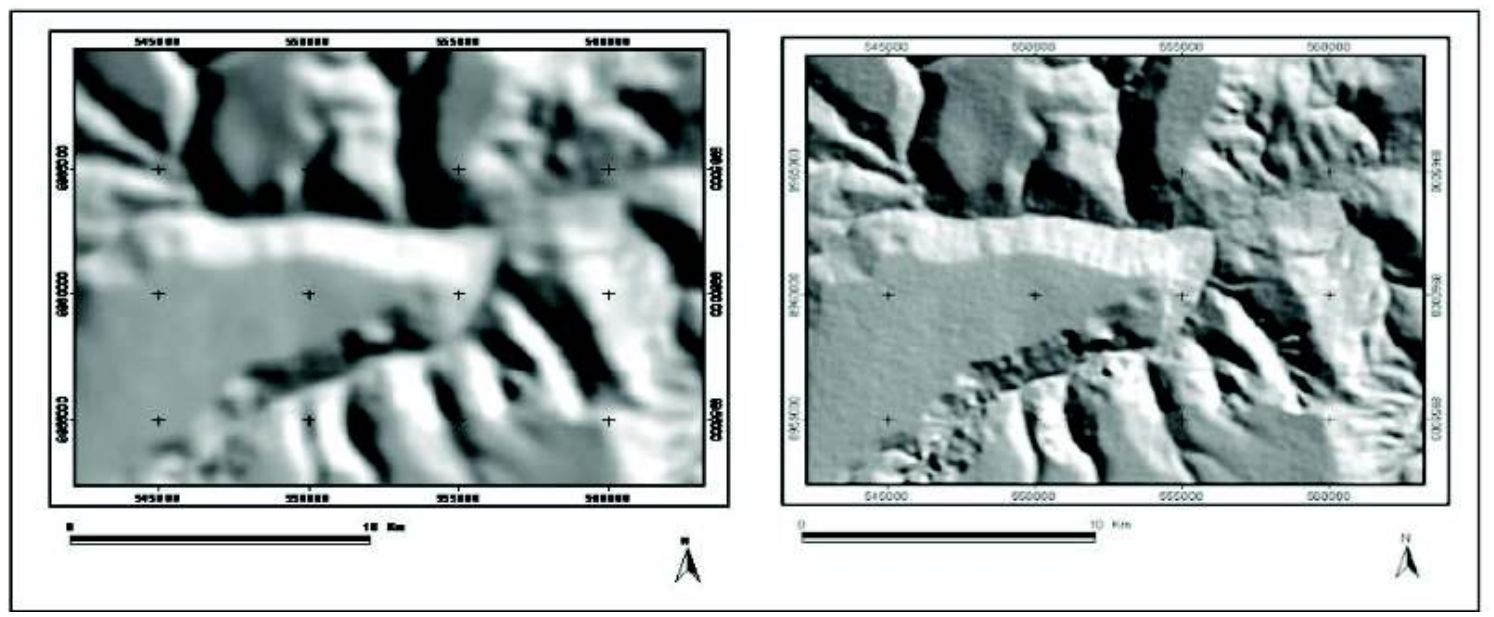

Figura 2 - 2a Relevo Sombreado, resolução de 90 m (original SRTM). 2b Relevo Sombreado, resolução de $30 \mathrm{~m}$ (refinado por Krigagem) visualização em escala compatível a 1:100.000

Assim, o mapeamento geomorfológico procura evidenciar uma síntese de todas as variáveis do meio físico, apontando para as potencialidades e fragilidades do ambiente, posto que é inconcebível entender a gênese e a dinâmica das formas de relevo sem que se entenda antes o mecanismo motor de sua geração, sem que perceba as diferentes interferências dos demais componentes (geologia, solos, cobertura vegetal, clima e ação antrópica) em uma determinada Paisagem ou Unidade de Paisagem (ROSS, 1990). O mapeamento realizado apontou para este pressuposto, o qual as Unidades Geomorfológicas foram subdivididas hierarquicamente em níveis escalares desde Unidades Morfoestruturais na classificação de Ross (1992), até modelados correspondentes ao $4^{\circ}$ taxon Formas de Relevo Individualizadas da Unidade de Padrão de Formas Semelhantes ( $3^{\circ}$ taxon). Em primeiro estágio, foram cartografadas as formas de diferentes tamanhos e em planos secundários, representando a morfometria, a morfogênese e a morfocronologia, que tem vínculo direto com a tipologia das formas.

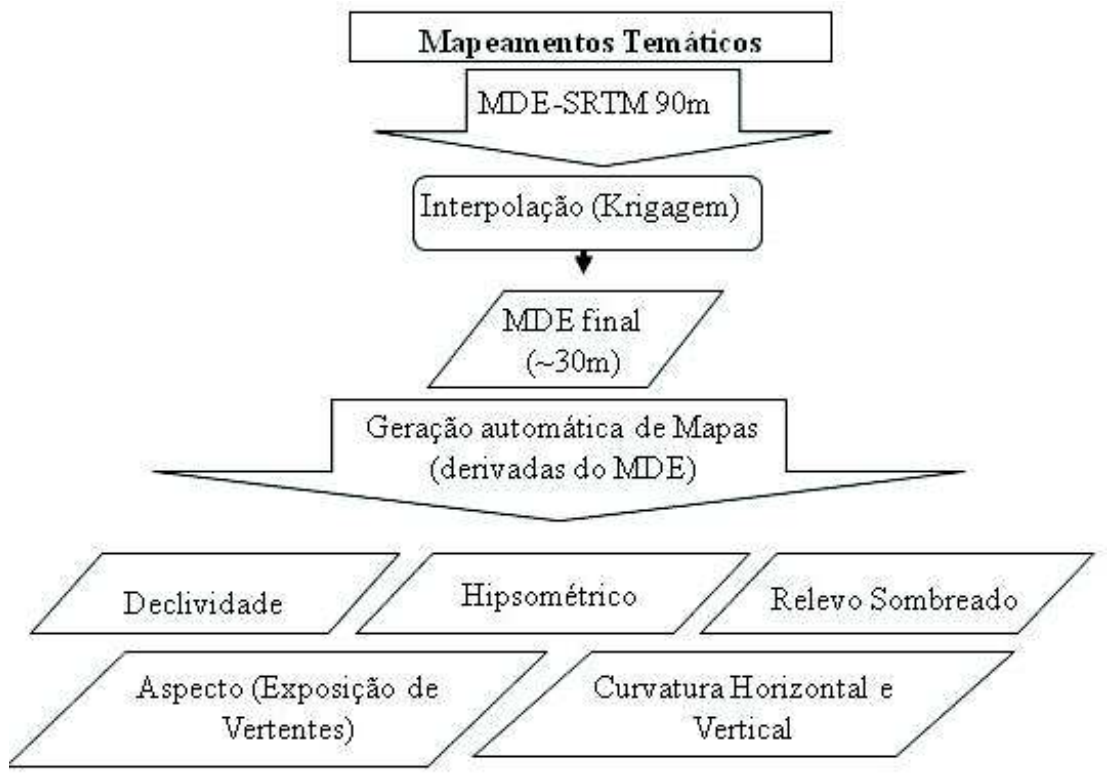

Figura 3 - Fluxograma das etapas de geração dos Mapas Temáticos

Seguindo a metodologia proposta por Ross (op. cit.), o primeiro e segundo taxon, correspondendo às Unidades Morfoestruturais e Unidades Morfoesculturais respectivamente, foram identificados através do mapa de relevo sombreado (shaded relief), isolinhas hipsométricas com 
eqüidistâncias de $100 \mathrm{~m}$, além do auxílio da imagem óptica do sensor ETM+, também em $30 \mathrm{~m}$ de resolução, e do mapa geomorfológico Folha SC.24.X.C - Paulo Afonso (IBGE, 1997). Na representação cartográfica, cada Unidade Morfoestrutural foi identificada por uma família de cor e cada Unidade Morfoescultural foi representada pelos tons de cores correspondentes às das respectivas Unidades Morfoestruturais.

A compartimentação do terceiro taxon (as Unidades Morfológicas ou Padrões de Formas Semelhantes), que está contida nas Unidades Morfoesculturais, é identificada por conjuntos de tipologias de formas que guardam entre si elevado grau de semelhança quanto ao tamanho de cada forma e ao aspecto fisionômico da rugosidade topográfica ou das diferentes intensidades dos padrões de dissecação de relevo proporcionados por diferentes intensidades de drenagem (ROSS, 1990 e 1992). Estes padrões são influenciados pelos canais de drenagem, tanto temporário quanto perenes, sofrendo assim influência direta do clima atual (SPÖRL, 2001).

A caracterização deste taxon foi procedida através da vetorização em tela apoiada pela Imagem de Relevo sombreado (shaded relief), dos mapas de declividade, hipsométrico, de curvatura vertical e horizontal, das isolinhas de 40 e 20 e $10 \mathrm{~m}$ de eqüidistância, observação do padrão de drenagem e a identificação de estruturas, além do auxílio da imagem óptica digital processada. Esses produtos foram sobrepostos em ambiente SIG. Assim, a caracterização geomorfológica baseou-se na identificação de "manchas" de padrões de formas de relevo semelhantes entre si.

As Unidades Morfológicas ou Padrões de Formas Semelhantes ( $3^{\circ}$ taxon) são identificadas por um conjunto de letras e algarismos arábicos. As letras representam a natureza genética dos Padrões de Formas Semelhantes, que podem ser 'A' - formas de Acumulação, identificadas por planícies de diferentes gêneses (marinha, fluvial...) e 'D', formas de Denudação (dissecação), esculpidas pelo desgaste erosivo como morros, serras, chapadas etc. (Quadro 1). Os algarismos são extraídos da Matriz dos Índices de Dissecação do Relevo. Estes números foram obtidos através da dimensão interfluvial média e do entalhamento médio dos vales, de acordo com Quadro 2 proposto por Ross (1992), identificando assim o $4^{\circ}$ taxon.

A matriz representa os Índices de Dissecação do Relevo demonstrando que, quanto maior for o valor numérico expresso pelo conjunto dos dois algarismos arábicos, maior será a dissecação e vice-versa. Por exemplo, o conjunto de algarismos 14 representa um menor índice de dissecação do relevo que o conjunto dos algarismos 35.

Devido à representatividade e importância dada pela população local às Formas esculpidas em Vales Fluviais estabelecidos por paleo-drengem (Ddv) e denominadas por 'Baixas' pelas comunidades indígenas, esta foi identificada como um Padrão de Formas específico.

Quadro 1 - Padrões de Formas do Relevo

\begin{tabular}{|l|l||}
\hline \multicolumn{2}{|c|}{ FORMAS DE RELEVO (PADRÕES DE FORMAS SEMELHANTES) } \\
\hline \multicolumn{2}{|c|}{ D - Denudação (dissecação) } \\
\hline Da - Formas com topos Aguçados & De - Formas de Escarpas \\
Dc - Formas com topos Convexos & Dv - Formas de Vertentes \\
Dt - Formas com topos Tabulares & Ddv - Formas de Vales (marcas de paleo-drenagem) \\
Dp - Formas de superfícies Planas & A - Acumulação (deposição) \\
\hline \multicolumn{3}{|c|}{ Apf - Formas de Planície Fluvial } \\
\hline
\end{tabular}

Nesta pesquisa foi proposta a inferência ou determinação do Índice de Dissecação do Relevo a partir da análise visual de perfis topográficos elaborados automaticamente através do MDE-SRTM refinado de $30 \mathrm{~m}$ utilizando o software Global Mapper 8 (GLOBAL MAPPER, 2007). Neste programa, é possível traçar perfis topográficos de forma automática a partir de Modelos Digitais de 
Terreno Assim, em cada Padrão de Forma Semelhante ( $3^{\circ}$ taxon) mapeado, foram traçados perfis topográficos representativos e analisados visualmente a dimensão interfluvial e o grau de entalhamento dos vales, a fim de classificar o índice de dissecação de cada Unidade Morfológica (Figura 4).

Como ilustrado no perfil abaixo (Figura 4), a Unidade Morfológica indicada refere-se a um Conjunto de Formas Dc41, ou seja, Conjuntos de Formas com topos convexos com entalhamentos médios dos vales forte, entre 40 e $80 \mathrm{~m}$ (dígito 4) e dimensão interfluvial média muito grande acima de $1500 \mathrm{~m}$ (digito 1$)$.

A identificação do $4^{\circ}$ taxon se dá pela representação individual de cada componente do $3^{\circ}$ táxon, constituindo assim nas Formas de Relevo Individualizadas. Esse taxon refere-se assim às formas de topos arrendados ou convexos e vales entalhados que, individualmente, se caracterizam por colinas com determinadas formas de tamanho, inclinação das vertentes e geradas por erosão de determinado ambiente climática.

Quadro 2 - Matriz dos Índices de Dissecação do Relevo

\begin{tabular}{|c|c|c|c|c|c|}
\hline $\begin{array}{l}\text { DIMENSÃO INTERFLUVIAL } \\
\text { MÉDIA (CLASSES) } \\
\text { GRAUS DE ENTALHAMENTO } \\
\text { DO VALE (CLASSES) }\end{array}$ & $\begin{array}{l}\text { MUITO GRANDE (1) } \\
\text { > } 1500\end{array}$ & $\begin{array}{l}\text { GRANDE (2) } \\
1500 \text { A } 700\end{array}$ & $\begin{array}{l}\text { MÉDIA (3) } \\
700 \text { A } 300\end{array}$ & $\begin{array}{l}\text { PEQUENA (4) } \\
300 \text { A } 100\end{array}$ & $\begin{array}{c}\text { MUITO PEQUENA (5) } \\
<100 \mathrm{M}\end{array}$ \\
\hline Muito Fraco (1) (< de $10 \mathrm{~m})$ & 11 & 12 & 13 & 14 & 15 \\
\hline Fraco (2) (10 a $20 \mathrm{~m})$ & 21 & 22 & 23 & 24 & 25 \\
\hline Médio (3) (20 a 40 m) & 31 & 32 & 33 & 34 & 35 \\
\hline Forte (4) (40 a $80 \mathrm{~m}$ & 41 & 42 & 43 & 44 & 45 \\
\hline Muito Forte (5) (> $80 \mathrm{~m})$ & 51 & 52 & 53 & 54 & 55 \\
\hline
\end{tabular}

Fonte: Ross (1994)

\section{ABORDAGEM ESCALAR PROPOSTA}

A compartimentação e mapeamento geomorfológico que foram propostos neste estudo procuraram contemplar as três noções de Escala apresentadas por Queiroz-Filho (2005). A Escala cartográfica ou gráfica proposta foi de 1:100.000. A escala de análise ou geográfica será dada na interface regional-local, posto que a área de estudo compreende espaços territoriais de cinco municípios da Região Econômica Nordeste do Estado da Bahia.

A Escala dos fenômenos será estabelecida pela adoção da metodologia de mapeamento e taxonomia do relevo proposta por Ross (1992), no caso, os fenômenos mapeados tratam-se das Formas de Relevo. Assim, como a escala cartográfica proposta é de 1:100.000, e, de acordo com o estabelecido por Ross (op. cit), com esta escala há possibilidade de se mapear processos e formas concernentes até o $4^{\circ}$ táxon de sua proposta metodológica.

\section{RESULTADOS E DISCUSSÕES}

Os produtos derivados do MDE-SRTM a partir do refinamento da resolução espacial de $90 \mathrm{~m}$ para $30 \mathrm{~m}$ pelo tratamento geoestatístico por krigagem, possibilitou uma melhor qualidade visual dos mapas derivados e curvas de nível hipsométricas com eqüidistâncias menores.

A melhoria da resolução espacial proporcionou uma melhor interpretação dos dados topográficos, além de uma melhor delimitação dos compartimentos geomorfológicos. Foram derivados, assim, mapas de declividade, curvatura vertical e horizontal, exposição de vertentes (aspecto), sombreamento topográfico, e, a partir do fatiamento do MDE, ou seja, da atribuição de classes altimétricas, obteve-se o mapa hipsométrico (Figura 7), que permitiu a identificação visual dos modelados e outros compartimentos geomorfológicos. 
A partir da derivação do Modelo de Relevo Sombreado (Figura 5) e do Mapa de Declividade (Figura 6), foi possível distinguir cada padrão de dissecação conspícua à respectiva Unidade Geomorfológica mapeada. Foram a base para o mapeamento geomorfológico na escala 1:100.000.

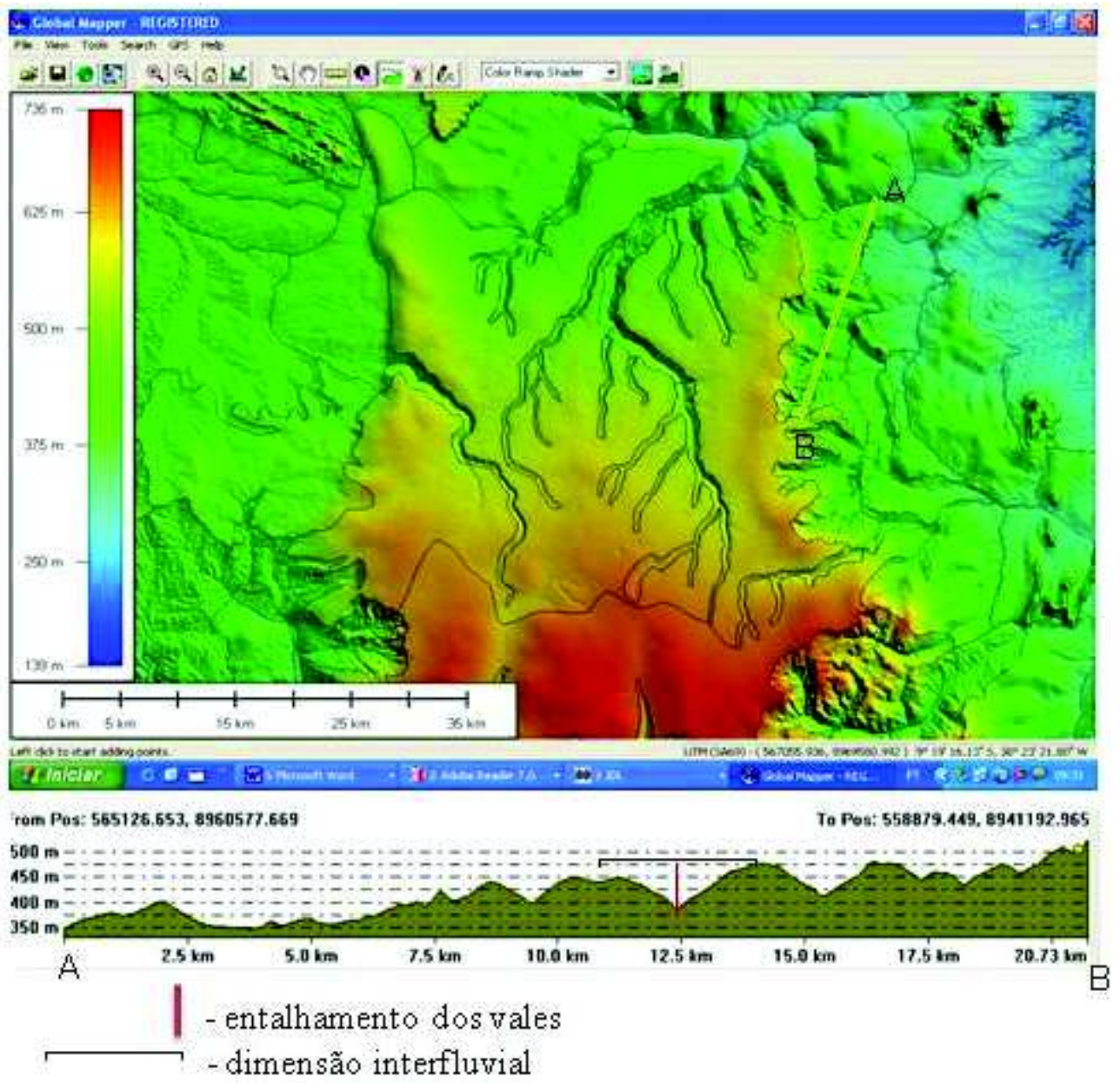

Figura 4 - a) Vista do software Global Mapper 8: MDE (Relevo Sombreado) com escala gráfica e vertical; b) Perfil topográfico de uma Unidade Morfológica (Padrão de Formas Semelhantes

\section{ANÁLISE DESCRITIVA DO RELEVO DA ECORREGIÃO RASO DA CATARINA E ENTORNO}

Os produtos derivados do MDE-SRTM foram a base para o mapeamento geomorfológico na escala 1:100.000 (Figura 8). Ressalta-se que foi imprescindível o detalhamento alcançado a partir do refinamento da resolução espacial dos dados MDE-SRTM de $90 \mathrm{~m}$ para $30 \mathrm{~m}$ pelo tratamento geoestatístico por krigagem (Figura 2), o que possibilitou uma melhor qualidade visual dos mapas derivados e curvas de nível hipsométricas com eqüidistâncias menores.

$\mathrm{Na}$ área de estudo, a parte delimitada como Unidade Morfoescultural das Chapadas do Raso da Catarina, inserida na Unidade Morfoestrutural dos Planaltos da Bacia de Tucano- Jatobá, representa a unidade de maior extensão e, estruturalmente, coincide com a Bacia de Tucano Norte, cuja litologia é correspondente às rochas que a compõem.

Ab'Saber (2006) afirmou que, de acordo com expressões populares, a palavra 'raso' tem um significado duplo. Na essência, diz respeito ao tipo de topografia, referindo-se a uma área ou sub-região de relevo muito plano, a que se acrescenta a idéia de uma área de grande extensão com vegetação homogênea. Em alguns casos, prossegue o autor destacando a idéia de que os rasos são constituídos por solos arenosos. Em outras circunstâncias e locais, apresentam-se como chão pedregoso, atapetados por um vasto lençol de cascalho. Nesse sentido, à luz do autor, o Raso da Catarina 
trata-se de uma baixa chapada arenítica, colocada ao norte da Bahia, entre o rio São Francisco e o Vaza-Barris, e ladeada por dois vales de direção sul-norte: o Macururé e Xingozinho, é recoberta extensivamente por caatingas primárias e tem aproximadamente $70 \mathrm{~km}$ de eixo menor (oeste-leste) e $80 \mathrm{~km}$ de eixo maior (sul-norte). Possui pouco mais de $400 \mathrm{~m}$ de altitude, evidenciando, porém, uma discreta ascensão de noroeste para sudeste, desde a aldeia de São Francisco até os arredores de Jeremoabo.

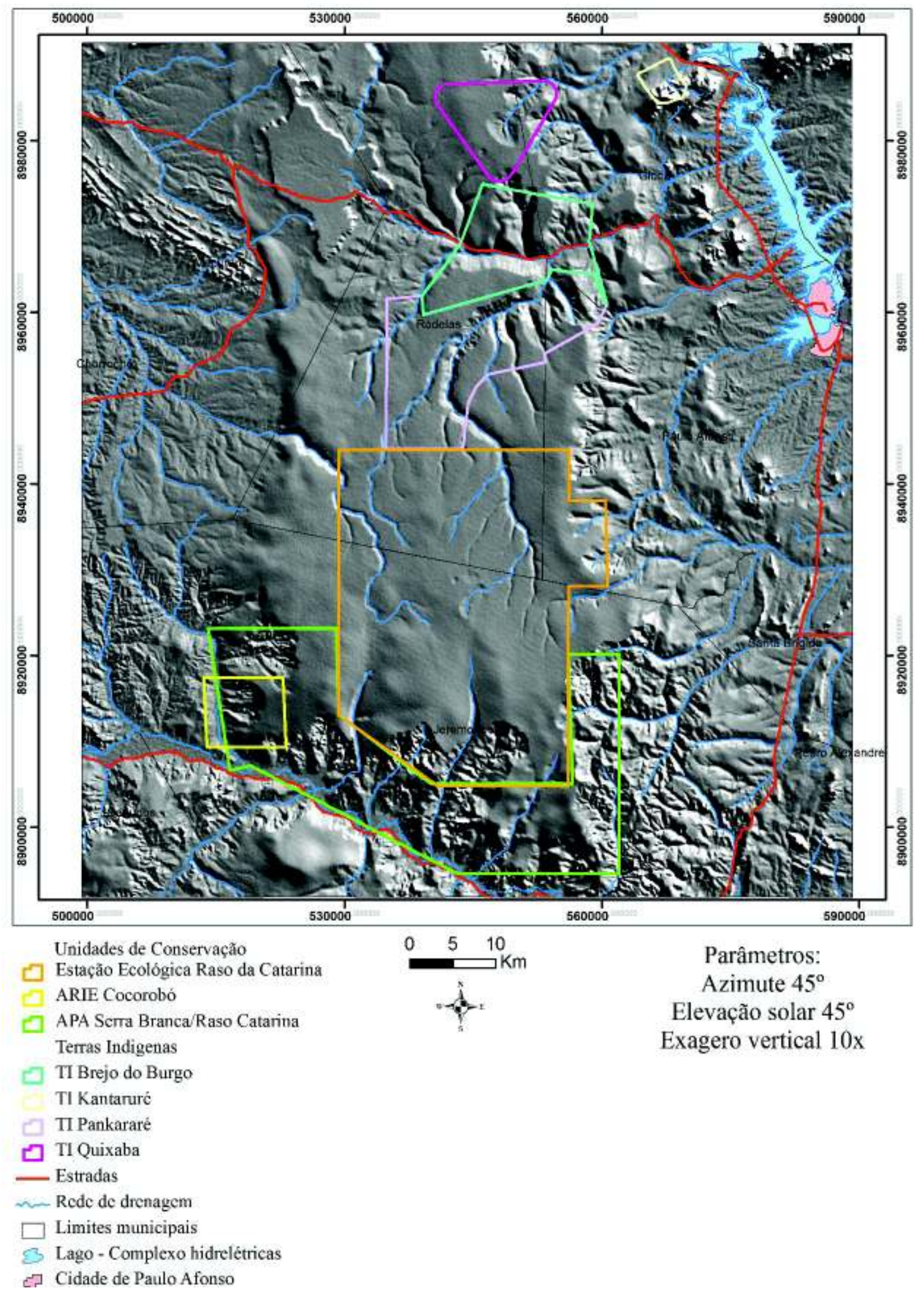

Figura 5 - Relevo Sombreado 


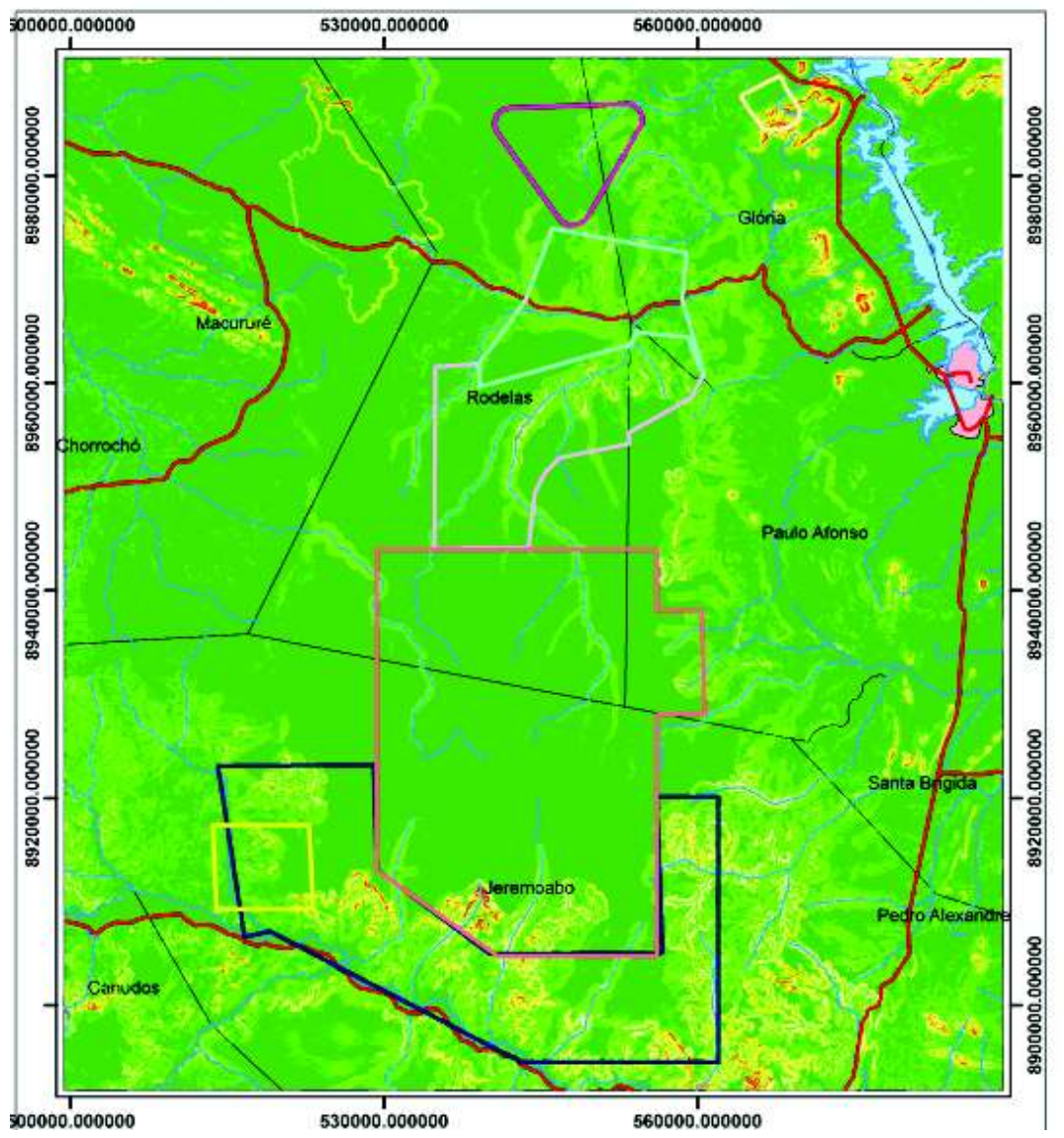

Classes de declividade (\%)
$\square 0-6$
$\square 6-12$
$12-20$
$\square 20-30$
$\square 30-40$
$40-45$
$>45 \%$

Unidades de Conservação

Estação Ecológica Raso da Catarina ARIE Cocorobó

ఐ APA Serra Branca/Raso Catarina Terras Indígenas

-7 TI Brejo do Burgo

Tl Kantaruré

7) TI Pankararé

TI Quixaba

- Estradas

n. Rede de drenagem

$\square$ Limites municipais

Lago - Complexo hidrelétricas Cidade de Paulo Afonso

Figuras 6 - Mapa de Declividade

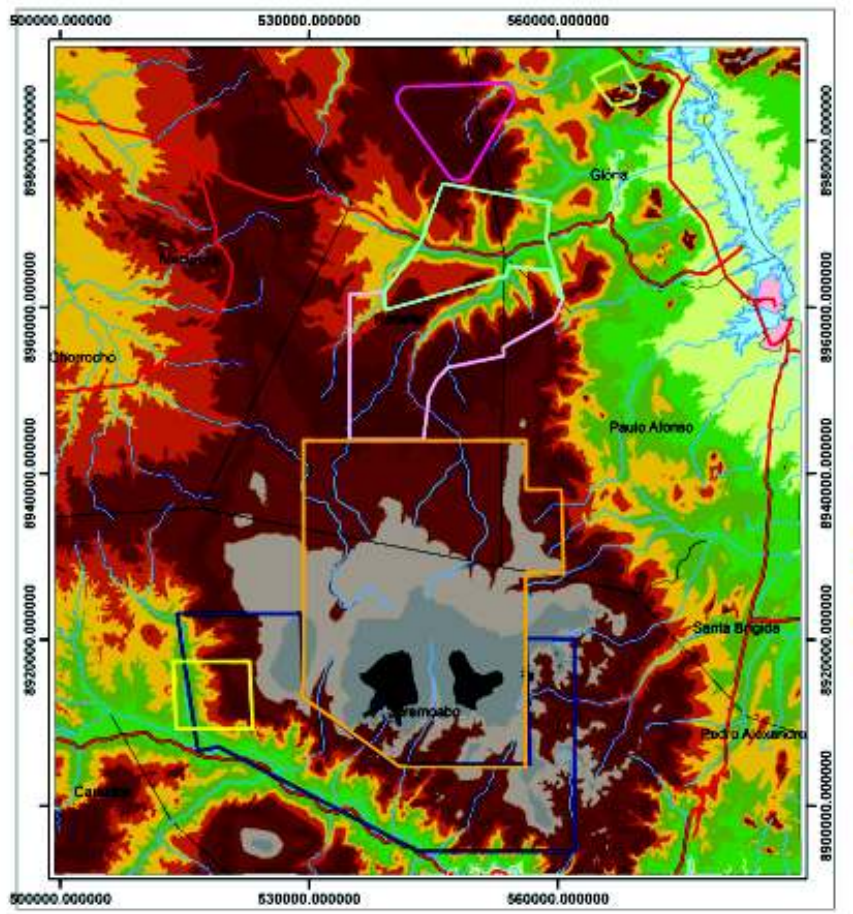
Hipsometria (m) $142-200$ $\square 200-260$ $260-300$ $300-340$ $340-380$ $380-420$ - 420 - 460 - $460-500$ - $500-550$ $550-600$ $600-650$ $650-700$ $700-736 \mathrm{~m}$
Unidades de Conservaçăo
Estaçăo Ecológica Raso da Catarina ARIE Cocorobó
ㅁ APA Serra Branca/Raso Catarina Terras Indigenas
TI Brejo do Burgo
Tl Kantaruré
7. TI Pankararé
ㅁ TI Quixaba
- Estradas
- Rede de drenagem
$\square$ Limites municipais
5 Lago-Complexo hidrelétricas
e Cidade de Paulo Afonso

बiv

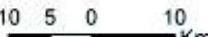

Figura 7 - Mapa Hipsométrico 

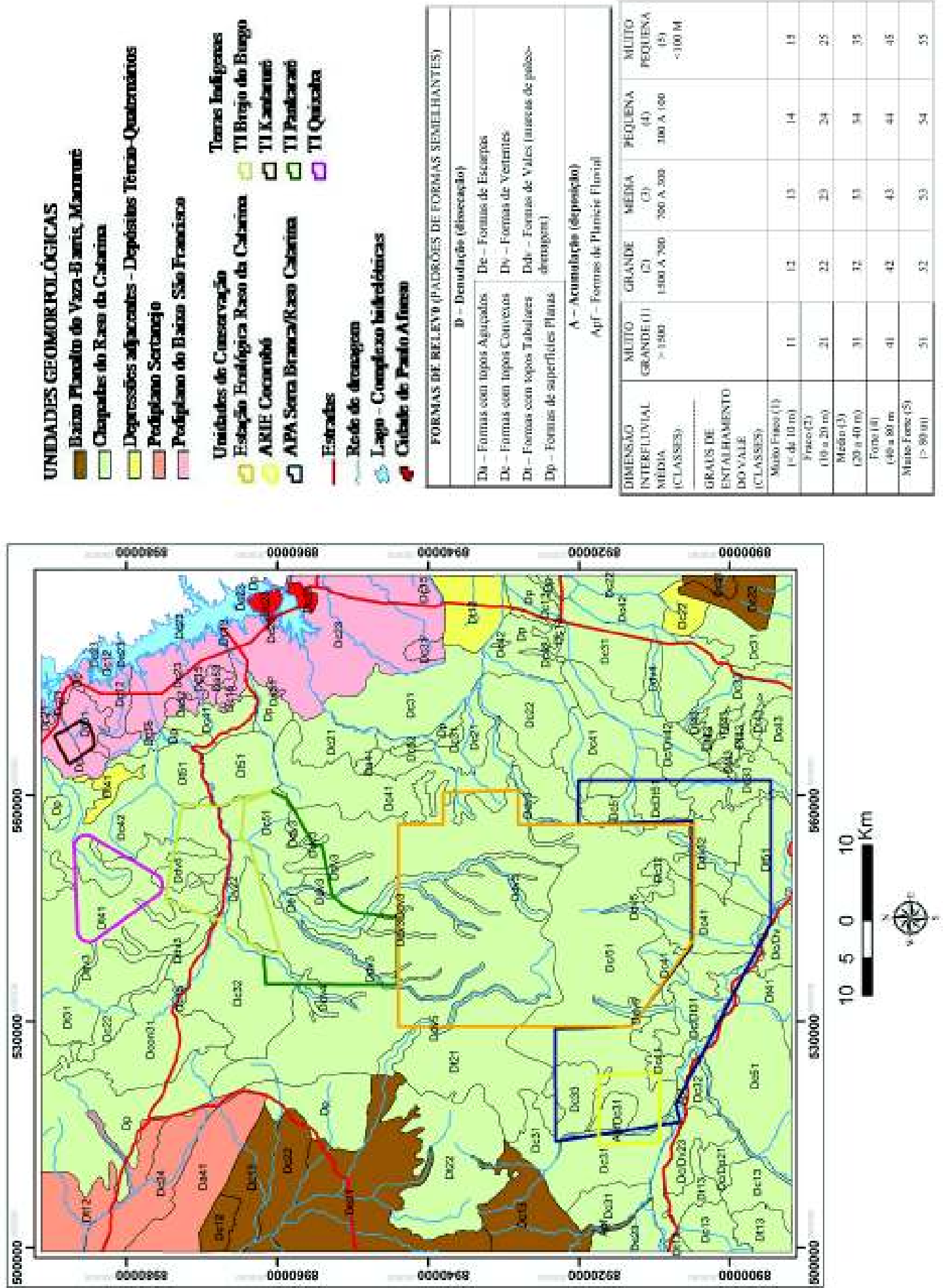

Figura 8 - Mapa Geomorfológico 
De acordo com a caracterização proposta, a Unidade Morfoescultural das Chapadas do Raso da Catarina é composta por vários Padrões de Formas Semelhantes, devido à sua própria extensão, sua característica estrutural e dinâmica geomórfica. Um Padrão de Formas com distribuição significativa na área são as Formas em topos tabular do Tipo Dt21, refere-se ao Raso da Catarina sensu stricto, cuja descrição feita por Ab'Saber (op.cit.) coincide, em muitos aspectos, com este Tipo de Forma.

O Raso da Catarina sensu stricto localiza-se na parte central da área, onde se encontram a Estação Ecológica Raso da Catarina e a Terra Indígena Pankararé. Trata-se de uma superfície tabular sustentada por rochas areníticas da Formação Marizal, com declividades em torno de 3\% e, por vezes, em até $6 \%$. A altimetria varia ente 400 a $440 \mathrm{~m}$. A cobertura pedológica é constituída por Neossolos Quartzarênicos com cobertura vegetal de Caatingas Arbóreas e Arbustivas conservadas (Figuras 9).

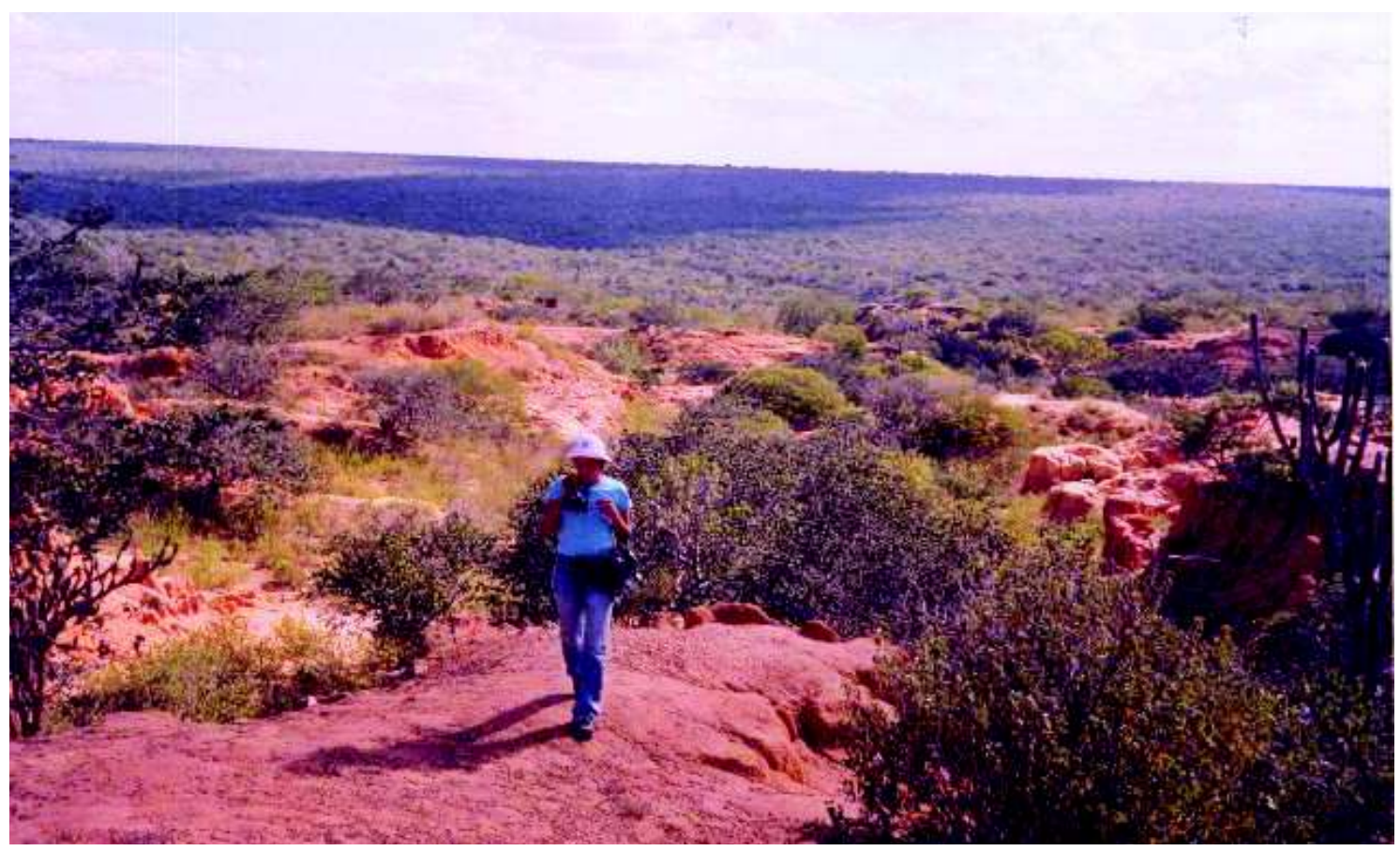

Figura 9 - Ao Fundo, Tipo de Formas Dt21, No primeiro plano, área de erosão natural em área limite do mesmo compartimento

A continuidade desse modelado só é interrompida quando existe interceptação por vales com encostas retilíneas, sendo classificados como Padrão de Formas Semelhantes com Denudação (dissecação) em Vales (Ddv). Esses Vales são evidências de paleodrenagem que teve papel preponderante na dissecação do relevo em algum momento do Plio-pleistoceno, quando a região se encontrava sob clima úmido (SUGUIO, 1999). Atualmente, esses vales são constituídos por áreas receptoras e dispersoras de águas pluviais, sedimentos e matéria orgânica das encostas, o que lhes proporciona um aumento relativo na fertilidade natural dos solos localizados nos fundos desses vales, sendo aproveitados para o desenvolvimento de agricultura familiar pela comunidade Indígena Pankararé, esta denomina tradicionalmente os vales de 'Baixas' (Figura 10).

Em alguns desses Vales, a dissecação realizada pelos cursos d'água ora existentes se tornou mais pronunciada, sendo facilitada por zonas de fraqueza como fraturas e/ou falhas existentes no pacote sedimentar, dando aos vales feições de verdadeiros canyons areníticos com paredões de declividade até $90^{\circ}$ e altura de até $100 \mathrm{~m}$. Este Tipo de Forma pode ser observado na Baixa do Chico (Figura 11) e Baixa Fechada, localizados na parte central do Raso da Catarina e na Baixa da Catarina no oeste desta Unidade, respectivamente. 

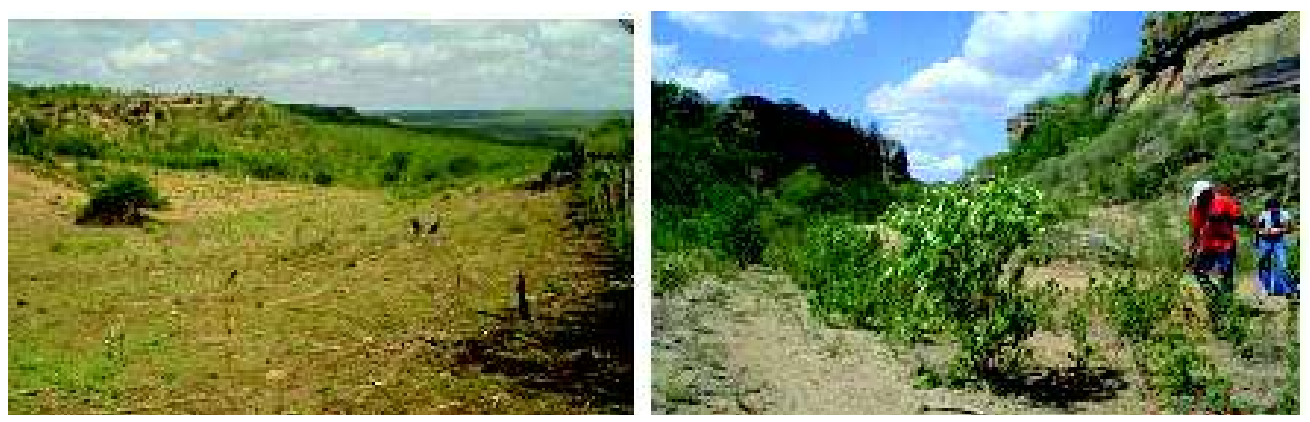

Figura 10 - Baixa do Amaro: Tipo de Forma Ddv3. Área antropizada, utilizada para agricultura familiar; ao Fundo, contrafortes do Raso da Catarina sensu stricto

Figura 11 - Baixa do Chico Tipo de Forma Ddv5 - Vale fortemente dissecado na forma de "canyons". Em evidência, paredões areníticos verticalizados, área também utilizada para agricultura familiar

Outro Padrão de Forma encontrado no Raso da Catarina sensu stricto localiza-se na parte sul por ser uma área de nascentes e topos com interflúvios amplos e com presença dos respectivos vales com Forma Ddv. Foi classificado como Tipo de Forma Dc51, ou seja, Formas com colinas amplas com dimensão interfluvial média acima de $1500 \mathrm{~m}$ e graus de entalhamento dos vales muito fortes, acima de $80 \mathrm{~m}$. A altimetria varia predominantemente entre 500 a $700 \mathrm{~m}$, com topos chegando à cota máxima de $736 \mathrm{~m}$. As declividades não ultrapassam 6\%, portanto, essas áreas possuem relevo plano a suave ondulado. Apresenta uma cobertura vegetal de Ecótonos de Vegetação: Caatinga Arbórea-Cerrado. Nas partes de contato com outros Padrões de Formas Dc41 e Dc33, tanto em sua porção sul, leste ou oeste, esse contato é, por vezes, de forma abrupta, em vertentes fortemente dissecadas, com presença de erosão acentuada e ravinamentos (Figura 12).

Esses Padrões de Formas Denudacionais Tipos Dc41 e Dc33 em Colinas com vertentes íngremes formam um conjunto de modelados fortemente dissecados. Sua base é formada por um relevo suave ondulado a ondulado, além da presença de relevos testemunhos, localizados entre o Raso da Catarina sensu stricto e a planície fluvial do rio Vaza-Barris. O trabalho de dissecação exercido pelos rios faz com que aflorem rochas de Formações subjacentes à Formação Marizal, como a Formação Poço Verde, São Sebastião e Grupo Ilhas, constituídas por rochas areníticas e meta-areníticas. A altimetria desses compartimentos varia entre 340 e $600 \mathrm{~m}$, as declividades quase sempre entre $12 \%$ a $20 \%$, ultrapassando $45 \%$ nas vertentes dissecadas e ravinadas. Possui solos arenosos na parte mais plana e ondulada e, nas vertentes dissecadas, solos litólicos, desenvolvendo, assim, uma vegetação de Caatinga Arbórea e Caatinga Arbustiva, respectivamente (Figura 13).
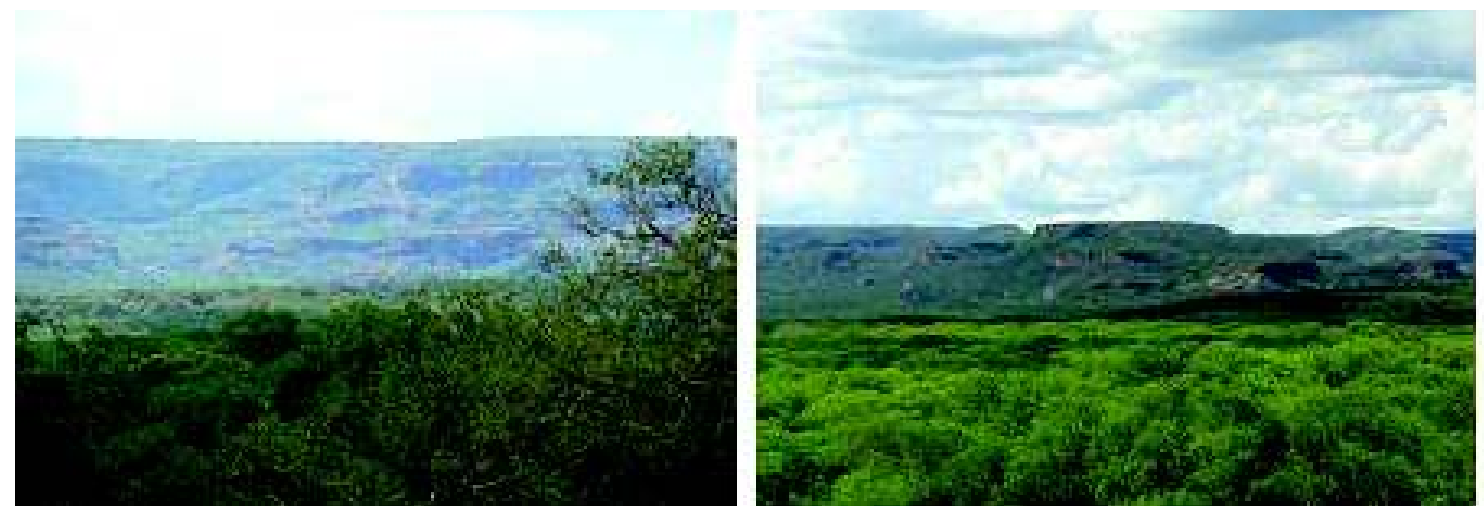

Figura 12 - Área de contato entre o Tipo de Forma Dc51 (Raso da Catarina parte sul). No alto, parte plana ao fundo e o Tipo Dc 41 vertentes íngremes dissecadas com presença de erosão acentuada

Figura 13 - Tipo de Forma Dc41, adjacente a planície fluvial do Vaza-Barris, presença de relevos testemunhos fortemente dissecados com marcas de erosão natural em suas vertentes 
Contígua a esses relevos dissecados, é identificada a Unidade Morfológica da Planície Fluvial do rio Vaza-Barris com Padrões de Formas do Tipo Acumulação de Planície Fluvial (Apf). O Vaza-Barris tem seu curso intensamente trabalhado e adaptado para o desenvolvimento de agricultura irrigada, tendo sua vazão controlada pela Barragem de Cocorobó, localizada em seu alto-curso. A altimetria varia entre 300 e $340 \mathrm{~m}$ e as declividades não ultrapassam $6 \%$. Com relevo plano a suave ondulado, possui solos cuja gênese está fortemente influenciada pela presença do curso d'água, sendo os solos pertencentes à Classe dos Vertissolos. A vegetação de Caatinga Arbustiva original foi substituída pelo uso antrópico destinado à agricultura irrigada nas margens do rio ou através de canais (Figura 14a), ou a presença de Caatinga Arbustiva antropizada (Figura 14b). Há também, além dessas características, um estabelecimento de vegetação higrófilas em seu leito menor, denotando alto grau de antropização (Figura 14c).

Adjacente à margem direita do Padrão de Formas do Vale do Vaza-Barris, há uma continuidade da Unidade das Chapadas do Raso da Catarina com o relevo igualmente dissecado que se apresenta em encostas íngremes com afloramentos das rochas areníticas do Grupo Ilhas e São Sebastião. Esses Padrões de Formas Semelhantes são denudacionais em colinas ou tabulares do Tipo Dc23, Dt23, Dc32, Dt13, Dc13 e Dc51.

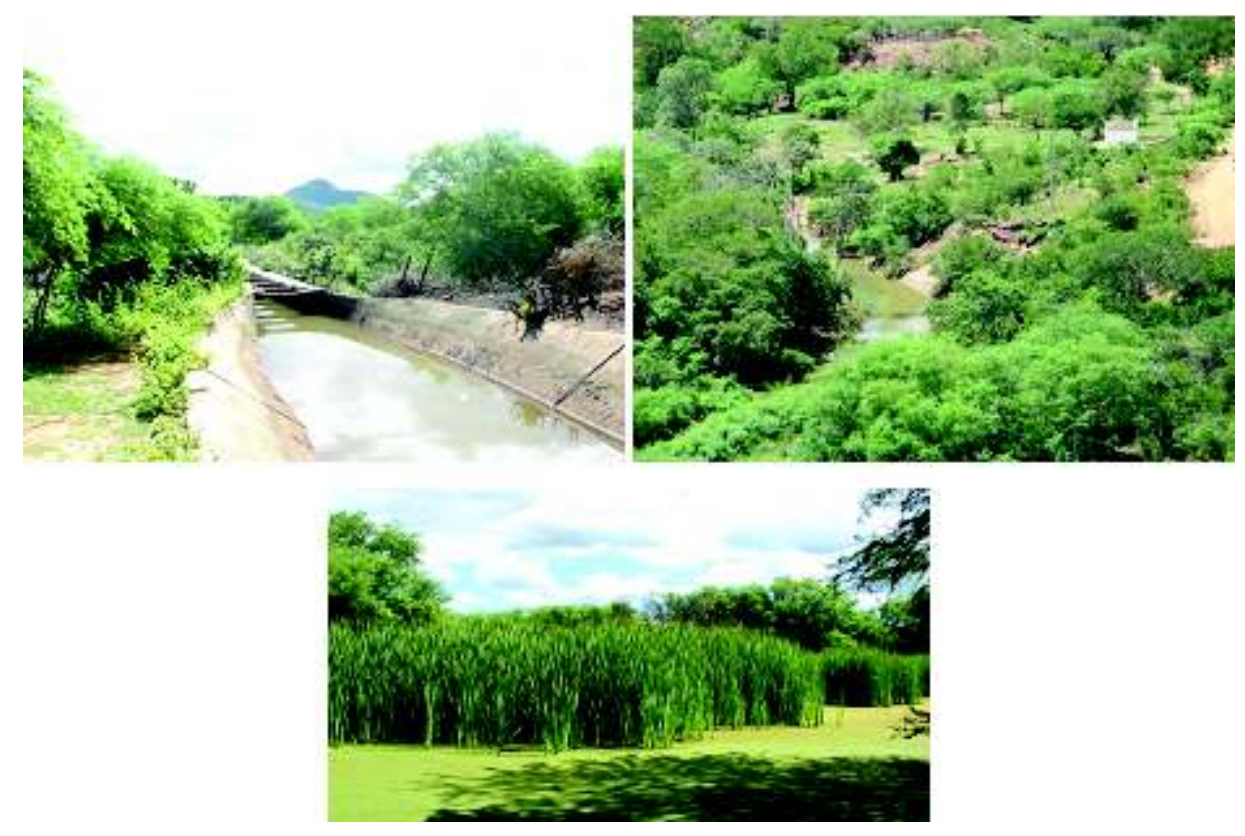

Figura 14 - Curso do Rio Vaza-Barris: a) canal da irrigação; b) Leito maior: com mata ciliar parcialmente degradada com presença de algarobas (Prosopis juliflora); c) vegetação higrófila em seu leito menor, denotando alto grau de antropização

Na parte norte da área, localiza-se um compartimento denominado Serra do Tonã, identificada como um Padrão de Forma Semelhante denudacional em Forma tabular do Tipo Dt31. Estruturalmente, a Serra do Tonã coincide com a Formação Santana, que se trata de uma seqüência de arenitos e calcários silicificados, além de siltitos e calcilutitos, também denominada de Seqüência Tonã depositada sobre a Formação Marizal. Os solos dessa área são rasos arenosos a pedregosos da Classe dos Cambissolos e com grau de fertilidade natural maior do que o encontrado nos Neossolos Quartzarênicos. A altimetria da Serra varia entre 500 na base até $600 \mathrm{~m}$ por ser uma superfície tabular ligeiramente côncava no sentido noroeste da sudeste da serra. Possui declividades inferiores a $6 \%$, variando de 0 a $3 \%$ e de 3 até $6 \%$ na parte superior, e de forma abrupta e em ressaltos passa do intervalo de 0 a $3 \%$ na base, superando $30 \%$ em suas vertentes. A vegetação varia entre Caatinga Arbustiva conservada em suas vertentes, passando por Caatinga Arbustiva antropizada intercalada com áreas de Uso antrópico (Figura 15). 
O Tipo de Forma Dc32, localizado a leste da Serra do Tonã, possui relevo movimentado com presença de Formas em colinas com declives médios. A denudação desse Tipo de Forma pode ser atribuída à maior densidade da rede de drenagem. Mesmo sendo de caráter intermitente e, por vezes, efêmero, possui grande poder erosivo quando em época das chuvas, com os solos profundos e arenosos, pertencentes à classe dos Neossolos Quartzarênicos e Vegetação Arbustiva (Figura 16).

$\mathrm{Na}$ Unidade Geomorfológica do Pediplano Sertanejo ( $3^{\mathrm{a}}$ taxon), localizada na porção noroeste da área, foram caracterizados Padrões de Formas Semelhantes com topos convexos do tipo Dc24. Essas Formas de relevo estão associadas a rochas graníticas gnáissicas da Faixa Sergipana. Possuem altimetria variando entre $370 \mathrm{~m}$, no vale do riacho Tim Tim, e até $510 \mathrm{~m}$ em relevos residuais. As declividades desses Tipos de Formas são bem características do Pediplano Sertanejo, não ultrapassando $6 \%$, somente em incisões estabelecida pela drenagem que chegam a até $12 \%$, e, em relevos residuais, podendo alcançar até $20 \%$ e, pontualmente, até $30 \%$ como na Serra da Cachoeira.
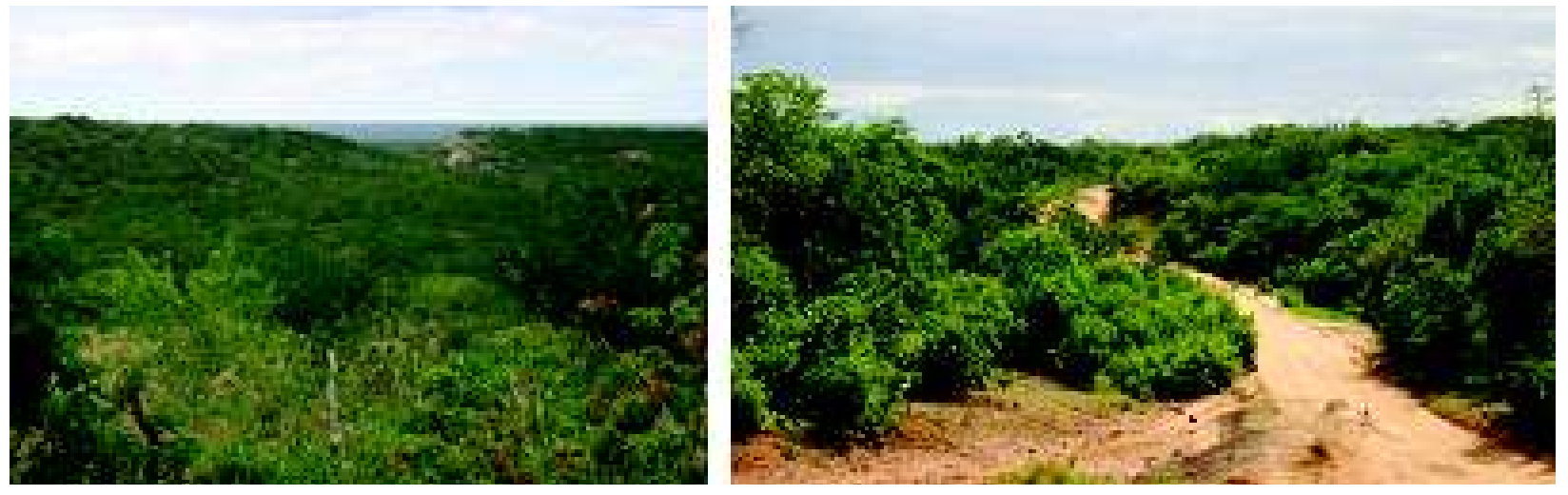

Figura 15 - Paisagem vista da Serra do Tonã

Figura 16 - Aspecto do Padrão de Forma Dc32

Esses modelados são, na realidade, relevos residuais contrapondo com o Padrão do Tipo Dt12 com topos tabulares, mais característicos dessa Unidade Geomorfológica, possuindo elevação entre 400 a 467 m e declividade que não ultrapassa 3\%. A Cobertura Vegetal desses dois Padrões de Formas é, essencialmente, Caatinga Arbórea em áreas com altitudes mais altas e nos vales dos rios. Na porção intermediária, é composto por Caatinga Arbustiva (Figura 17).

Pertencente à Unidade do Pediplano Sertanejo, é encontrado ainda o Padrão de Formas com topos aguçados do Tipo Da41 (Figura 18). Este modelado trata de um alinhamento de serras ou serrotes entrecortados por vales fluviais com forte controle estrutural, proveniente de rochas metamórficas do Complexo Marancó - Unidade Serrote do Juá. Possui altimetria variando entre 380 $\mathrm{m}$ nos vales fluviais no caso do riacho da Tranqueira, e de até acima de $700 \mathrm{~m}$ nos topos mais aguçados. Por conta dessa amplitude altimétrica, as declividades são acentuadas, ultrapassando, com facilidade, $30 \%$ e, em algumas serras, $45 \%$. A vegetação, neste Tipo de Forma, é constituída essencialmente por Caatinga Arbórea conservada.

A rede de drenagem do Pediplano Sertanejo é intermitente com cursos inseridos na Bacia do Baixo-médio São Francisco. O principal curso existente, nesta Unidade, é o Riacho Tim-Tim, que divide os Padrões Dc23 e Dt12. Este curso é responsável pelo maior grau de dissecação da área. Já os outros pertencentes a sua bacia de drenagem, provocam dissecação menos pronunciadas. A drenagem estabelecida no Padrão Da corta, perpendicularmente, as serras residuais, constituindo-se em um divisor de águas entre o Pediplano Sertanejo e o Baixo Planalto do Vaza-Barris.

Os Padrões de Formas de Semelhante referentes à Unidade Geomorfológica dos Baixos Planaltos do Vaza-Barris possuem sua base estrutural provenientes de rochas metamórficas da Unidade Macururé. Esses Padrões apresentam-se em Formas denudacionais com topos convexos Dc12 e Dc21, este último ocupando uma extensa área a leste do Raso da Catarina, possui padrão de drena- 
gem dendrítico responsável pela dissecação do relevo que é constituído, essencialmente, por morros com baixas declividades, não ultrapassando $6 \%$ e alcançando até $12 \%$ nos vales dos cursos d'água. A altimetria varia entre 381 até $500 \mathrm{~m}$, os solos são, essencialmente, rasos e pedregosos sobreposto por uma camada detrítica recobertos por vegetação arbustiva com presença de cactáceas e arbustos com grau acentuado de xeromorfismo (Figura 19). O pavimento detrítico rudáceo constituído por areias grossas, seixos e calhaus, denota a atividade erosiva comandada pelo intemperismo físico, evidenciando a extrema rusticidade climática regional e local.
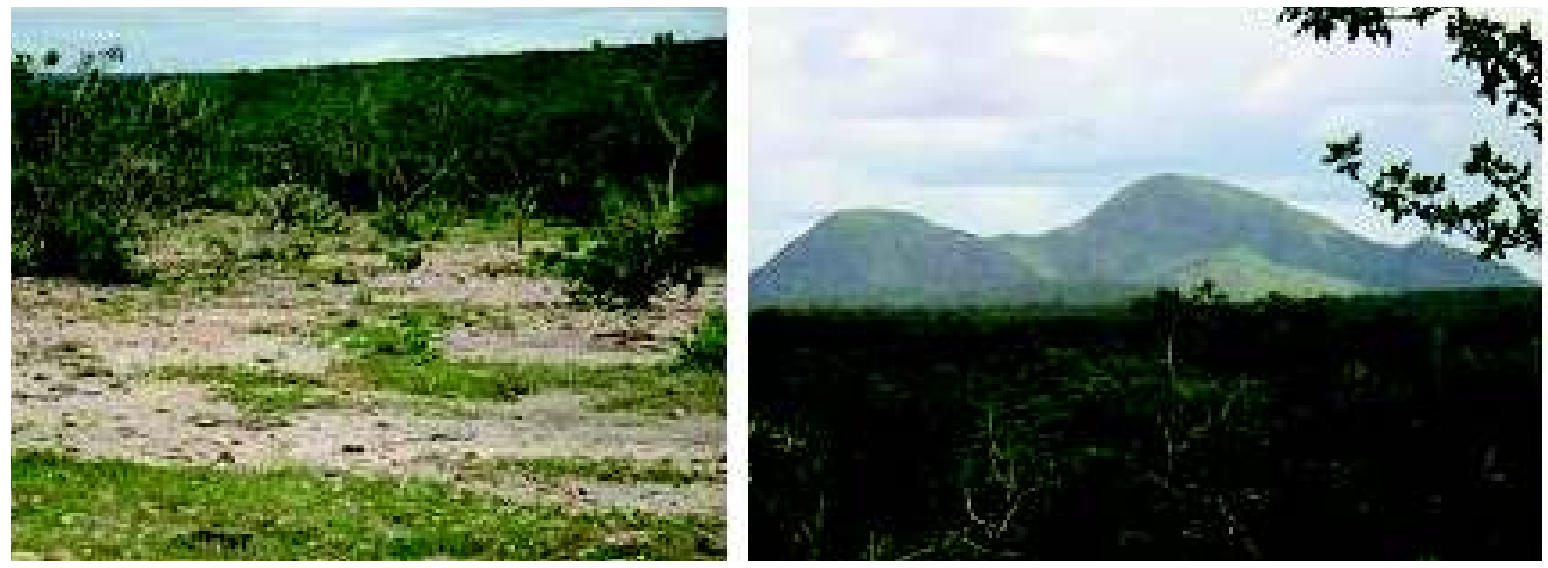

Figura 17 - Paisagem Típica do Pediplano Sertanejo

Figura 18 - Padrões de Formas Denudacionais com Topos Aguçados (Da41) da Unidade Geomorfológica Pediplano Sertanejo

Nas planícies fluviais, no entanto, a exemplo da Várzea da Ema e do riacho da Catarina, localizada no Tipo de Forma Dc21, devido à maior dissecação provocada pelos cursos d'água, foi possível o desenvolvimento de solos mais profundos e, conseqüentemente, uma Mata Ciliar constituída por Caatinga Arbórea e árvores com porte arbóreo semi-decidual (Figura 21). Nestas áreas, pode ser percebido o trabalho de transporte de areias exercido pelas águas fluviais intermitentes e torrenciais. São esses cursos os responsáveis pela configuração do relevo majoritariamente suave ondulado a ondulado.

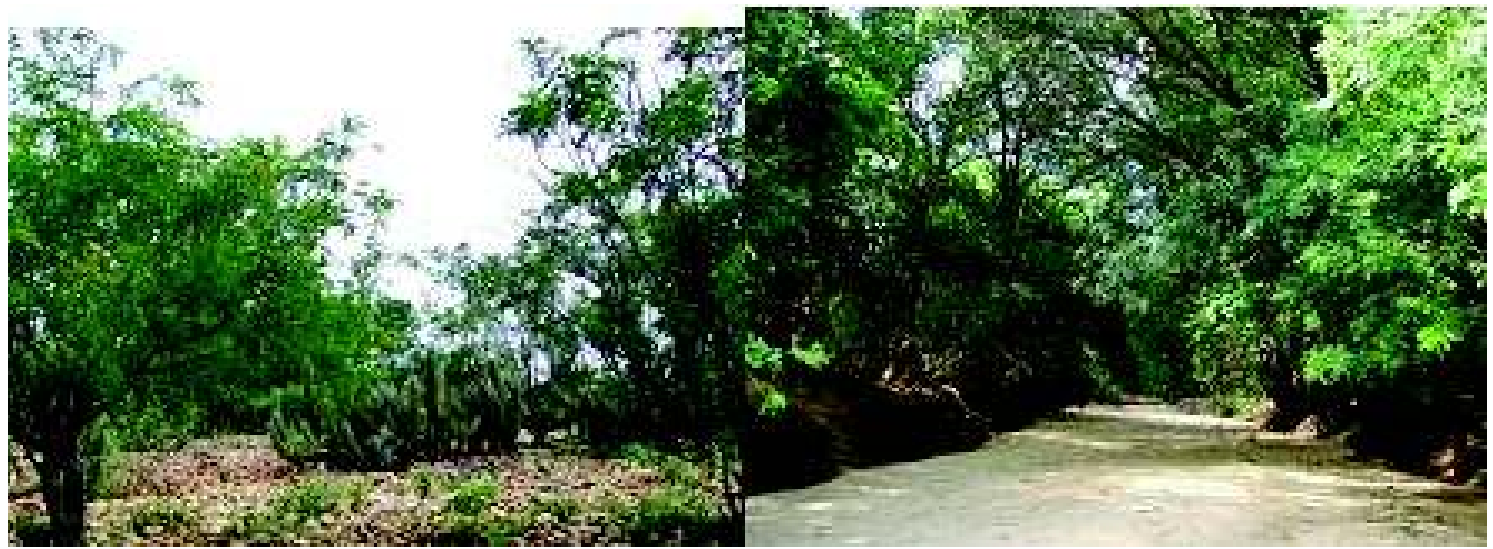

Figura 19 - Paisagem típica dos Baixos Planaltos do Vaza-Barris, Tipo de Forma Dc 21, pavimento detrítico sobreposto a solos litólicos recobertos por Caatinga Arbustiva

Figura 20 - Curso do Riacho da Catarina: Tipo de Forma Dc21 Baixos Planaltos do Vaza-Barris, presença de Mata ciliar constituída por árvores de elevado porte

Ao sul desses Padrões, encontra-se o Conjunto Formas com relevos mais dissecados em colinas do Tipo Dc13. Esses modelados possuem altimetria variando entre 341 a $380 \mathrm{~m}$ no vale do riacho Grande e Pedra Branca, afluente do rio Vaza-Barris e alcançando altitudes de até $480 \mathrm{~m}$, no 
limite norte deste com os Padrões de Formas do Raso da Catarina, no caso, do tipo Dc23. Esses dois riachos, por possuírem maior poder erosivo, promovem o grau de dissecação com dimensão interfluvial média entre 750 e $1750 \mathrm{~m}$ e o grau de entalhamento dos vales entre 20 a $40 \mathrm{~m}$ sobre Formas sustentadas por rochas metamórficas do Complexo Macururé, Unidade 2, refletida na declividade da área quase sempre entre 6 e 12\% e, nos vales, chegando a alcançar 20\% (Figura 21).

Na porção oeste da área, também são encontrados dois Conjuntos de Formas Semelhantes pertencentes aos Baixos Planaltos do Vaza-Barris. O primeiro se refere a um conjunto de relevos testemunhos com forte dissecação do Tipo Dc32 com declividades de até 30\%, ultrapassando facilmente $45 \%$, o outro Padrão de Forma se refere a uma área de relevo arrasado plano com deificação fraca do tipo Dc21.

Os setores nordeste e oeste da área de estudo são caracterizados pela Unidade Geomorfológica do Pediplano do Baixo São Francisco. É representada por Padrões de Formas diversos, estritamente relacionados à variedade da litologia. A nordeste tem-se o Padrão do Tipo Dc51 (Figura 22), constituindo um conjunto de serras com vertentes convexas e íngremes em sua face sudeste e com declividades superiores a 45\%, com altimetria variando entre $340 \mathrm{~m}$ na base até $600 \mathrm{~m}$ nos topos; em outras serras do mesmo compartimento, ultrapassam os $700 \mathrm{~m}$ como na Serra Grande, sustentadas, estruturalmente, por rochas areníticas metamorfizadas da Formação Tacaratu. Circundando este Padrão de Formas, há um relevo plano do Tipo Dp, além de Formas denudacionais em colinas do Tipo Dc12, constituídas por rochas metamórficas da Suíte Chorrochó. A vegetação desses compartimentos é, essencialmente, Caatinga Arbustiva conservada ou antropizada e Caatinga Arbórea nos setores de maior altimetria (Figura 22). A rede de drenagem, nesta área, é formada por cursos que possuem suas nascentes nas serras supra mencionadas, são de caráter efêmero e torrencial com suas águas desaguando no Lago do Complexo Hidrelétrico da CHESF.

Nesses compartimentos, são encontrados outros relevos residuais com o mesmo Tipo de Forma Dc51 (Figura 23), contudo, de menor expressão areal. Na base desses relevos, se sobressai o Pediplano do Baixo São Francisco com dimensão interfluvial medianamente amplo e baixa incisão dos vales. Estes são dissecados por uma rede de drenagem de padrão paralelo, com declividades de 0 a $6 \%$, chegando até $12 \%$ em alguns pontos. Presença de solos rasos da Classe dos Planossolos sustentando uma vegetação de Caatinga Arbustiva fortemente antropizada, tendo o substrato composto por rochas ígneas e metamórficas da Suíte Intrusiva Xingó. Após a cidade de Paulo Afonso, esse Padrão de Formas prossegue com o mesmo Tipo de Forma Dc23; contudo, observa-se um maior adensamento na rede de drenagem, e as primeiras denotariam uma maior dissecação do relevo - o que não se observa.
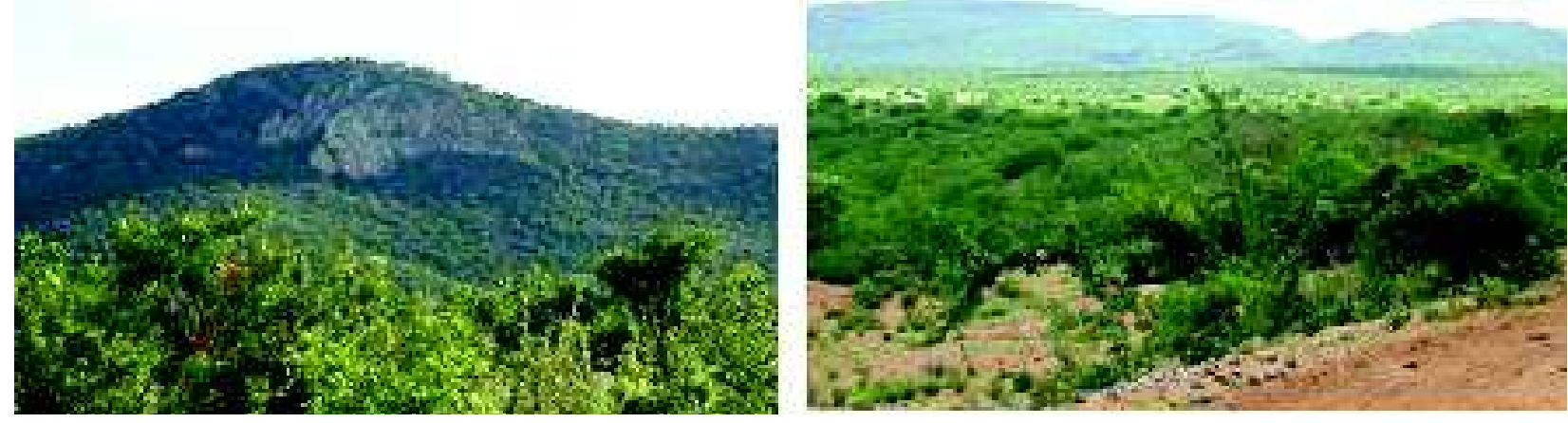

Figura 21 - Padrão de Forma Dc23 referente aos Baixos Planaltos do Vaza-Barris, Formas em morros convexos com setores de vertentes retilíneo com presença de afloramento rochoso, setor côncavo-convexo com presença de Caatinga Arbórea

Figura 22 - Pediplano do Baixo-médio São Francisco: Relevo plano a suave ondulado (Dp-Dc12); ao Fundo, serras marginais representadas por Tipos fortemente dissecados (Dc51) 
Por fim, no limite sul do Pediplano do Baixo São Francisco, é encontrada a Unidade das Depressões adjacentes constituída por sedimentos Tércio-Quaternários. Referem-se a um Padrão de Formas com superfície plana do Tipo Dp, com declividades inferiores a 6\%, baixa densidade da drenagem e altimetria variando entre 300 a 380m e cobertos por Caatingas antropizada (Figura 24).
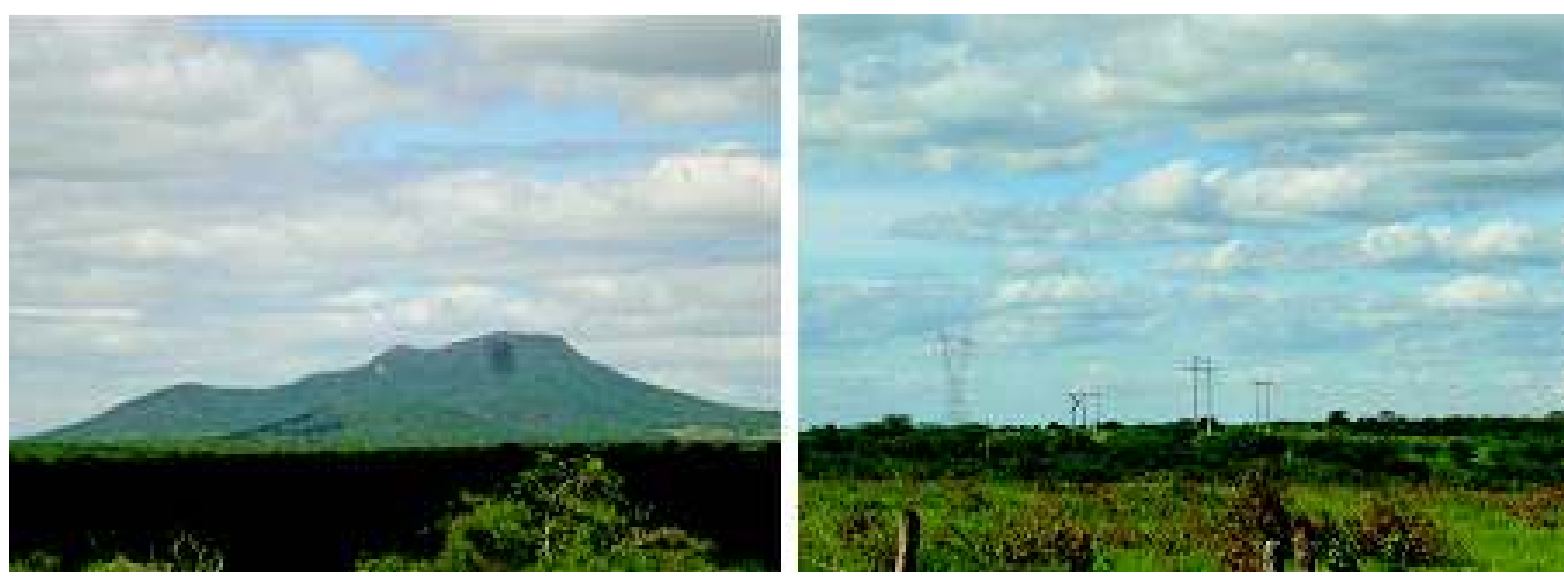

Figura 23 - Relevos residuais do Pediplano do Baixo-médio São Francisco altamente dissecados Padrão Dc51, caatinga arbórea base relevo plano o Padrão Dp, Caatinga Arbustiva conservada

Figura 24 - Padrão de Formas com superfície plana do Tipo Dp sobre Unidade da Depressão dos Sedimentos Tércio-Quaternários

\section{CONSIDERAÇÕES FINAIS}

Com este estudo procurou-se contemplar o objetivo de se caracterizar e mapear os compartimentos geomorfológicos de maneira elucidativa de parte da Ecorregião do Raso da Catarina e entorno. Adotou-se, como material e método de pesquisa, produtos e técnicas das Geotecnologias, mais especificamente do Sensoriamento Remoto, Sistemas de Informações Geográficas e Geoestatística, além de noções de cartografia temática e digital na confecção e edição final dos mapas.

Dessa forma, ressaltou-se a funcionalidade dos mapas derivados do Modelo Digital de Elevação, como o sombreamento topográfico (shaded relief), hipsométrico, declividade, exposição de vertentes (aspecto), curvatura vertical e horizontal, conseguida devido ao procedimento geoestatístico por krigagem que re-amostrou a resolução espacial do MDE-NASA de 90 para $30 \mathrm{~m}$. A partir desses mapas, foi procedida a caracterização e mapeamento geomorfológico em ambiente SIG por vetorização semi-automática.

A caracterização e mapeamento seguiram os pressupostos metodológicos da taxonomia de Ross (1992), chegando a caracterizar do $1^{\circ}$ ao $4^{\circ}$ táxon, propondo assim, um mapeamento na escala cartográfica de 1:100.000. O $3^{\circ}$ e $4^{\circ}$ táxon foi compartimentado por vetorização em tela e identificado pela determinação dos índices de dissecação do relevo através da elaboração de perfis topográficos automaticamente e interativos em software especifico de SIG, foi percebido a eficácia e praticidade desse procedimento. Ficou evidenciado, portanto, a possibilidade de aplicabilidade das geotecnologias aliada a metodologias já consagrada de mapeamento geomorfológico.

O mapeamento dos compartimentos geomorfológicos procurou sintetizar, através dos padrões de formas identificados, todos os mapas derivados do MDE-SRTM, bem como a análise descritiva do relevo procedida. Este documento se constitui assim em um instrumento base para outras análises e diagnósticos com objetivo de compreender a dinâmica da Paisagem de forma integrada.

\section{REFERÊNCIA BIBLIOGRÁFICA}

AB' SABER, Aziz Nacib. Raso da Catarina: Semi-árido com condições únicas de preservação da biodiversidade da Caatinga. Revista Scientific American Brasil. São Paulo. Ano 4. N $\square$ 49. 2006.

Mercator - volume 9, número 20, 2010: set./dez. 
ARAÚJO, Paulo César de. Análise da suscetibilidade a escorregamentos: uma abordagem probabilística. / Tese (Doutorado) - Universidade Estadual Paulista, Instituto de Geociências e Ciências Exatas. 172 f. Rio Claro - SP 2004.

ARGENTO, Mauro Sérgio Fernandes. Mapeamento Geomorfológico. In: GUERRA, Antonio Jose Teixeira; CUNHA, Sandra Baptista da. Geomorfologia : uma atualização de bases e conceitos. 365-391 pp. 4. ed Rio de Janeiro: Bertrand Brasil, 2001. 472p.

BARBOSA, Johildo Maria Salomão Figueiredo; Domingues, José Maria Landim. (coordenadores) Geologia da Bahia: texto explicativo. Salvador: Secretaria da Industria, Comercio e Mineração, 1996. 400p

BARROS, Rafael Silva de. Avaliação da Altimetria de Modelos Digitais de Elevação obtidos a partir de sensores orbitais. Tese de Doutorado -Universidade Federal do Rio de Janeiro, Programa de Pós Graduação em Geografia, 172f Rio de Janeiro, 2006.

BRASIL. MINISTÉRIO DAS MINAS E ENERGIA; Projeto RADAMBRASIL. Folhas SC. 24/25 Aracaju/ Recife : geologia, geomorfologia, pedologia, vegetação e uso potencial da terra. Rio de Janeiro: O Projeto, 1983. $852 \mathrm{p}$

BURROUGH, Peter A; MCDONNELL, Rachael A. Principles of geographical information systems. New York: Oxford University Press, 1998

CASSETI, Geomorfologia. Livro on-line 2006, acesso junho de 2006 disponível em: http://www.funape. org.br/geomorfologia/index.php

CPRM - Companhia de Pesquisa e Recursos Minerais. Sistemas de Informações Geográficas - SIG. Geologia e Recursos Minerais do Estado da Bahia: Mapas na escala 1: 1.000 .000 e 1: 2.000.000. V. 1: maio, 2003. 1 CD-ROM.

DDF-SEAGRI. Departamento de Defesa Florestal - Secretaria de Agricultura do Estado da Bahia. Mapa de Cobertura Vegetal e Uso do Solo do Estado da Bahia. V. 1: 1 CD-ROM 1998.

FALCÃO-SOBRINHO, José. O Relevo Elemento e Âncora, na Dinâmica da Paisagem do Valae, Verde e Cinza, do Acaraú, no Estado do Ceará. (Tese de Doutorado) Faculdade de Folosofia Letras e Ciências Humanas / FFLCH- Departamento de Geografia, USP, São Paulo, 2006

FREITAS, Marcos Wellausen Dias de. Estudo Integrado da Paisagem no Sertão Pernambucano (NE-Brasil) com o Uso de Sistemas de Informação Geográfica e Sensoriamento Remoto. $191 \mathrm{f}$ - Dissertação (Mestrado) em Sensoriamento Remoto. INPE - São José dos Campos, 2006

GOLDEN SOFTWARE. Surfer Version 8.0 - Surface Mapping System. Golden: Golden Software, Inc., 2005.

IBAMA - Instituto Brasileiro do Meio Ambiente. SISCOM-IBAMA. http://siscom.ibama.gov.br/shapes/ acesso em outubro de 2007

IBGE - Fundação IBGE. Manual técnico de geomorfologia. Coordenadores: Nunes, B. de A; Ribeiro, M.I. de C; Almeida, V.J. de; Natali Filho, T. Série Manuais Técnicos em Geomorfologia n. 5. Fundação IBGE, R. de Janeiro, 1995, $112 \mathrm{p}$.

IBGE - Projeto RADAMBRASIL - Folha SC. 24-X-C - Paulo Afonso. Escala: 1:250. 000. Geomorfologia, (Mapa Analógico). 1997

NUNES, Bernardo de Almeida, coord; JULIANTES, Regina Lamgruber, colab; CALDEIRON, Sueli Sirena, colab. Manual tecnico de geomorfologia. Rio de Janeiro: IBGE, 1995. 111p

LOBÃO, Jocimara Souza Brito, CHAVES, Joselisa.Maria, BANDEIRA, Fábio Pedro Souza Avaliação Multi-temporal (1987 e 2001) etnoecológica do uso do solo na Terra Indígena dos Pankararés-BA. São Paulo: GIS BRASIL 2003. 1-10 pp.

LOBÃO, Jocimara Souza Brito. Análise Sócio-Ambiental no Município de Morro do Chapéu-Ba: Baseada em Geotecnologias. 232f. Dissertação (Mestrado) - Instituto de Geociências, UFBA, Salvador, 2006. LOBÃO, Jocimara Souza Brito; e VALE, Raquel de Matos Cardoso. Microbacias na Região do Parque Estadual de Morro do Chapéu (PEMC): Um Modelo em SIG para Análise Ambiental. Anais do XIII SBSR Simpósio Brasileiro de Sensoriamento Remoto, Florianópolis-SC, Brasil 21-26 abril de 2007, INPE- Instituto de Pesquisas Espaciais, p. 2769-2776.

MMA - Ministério do Meio Ambiente. Biodiversidade Brasileira Avaliação e identificação de áreas e ações 
prioritárias para a conservação, utilização sustentável e repartição dos benefícios da biodiversidade nos biomas brasileiros. Brasília: MMA/SBF, 2002. 404 p.

MMA -Ministério do Meio Ambiente. Projeto de Conservação e Utilização Sustentável da Diversidade Biológica - PROBIO - Levantamento da Cobertura Vegetal e do Uso do Solo do Bioma Caatinga. Coordenador do Subprojeto: Washington de Jesus Sant'anna da Franca Rocha. Universidade Estadual de Feira de Santana (UEFS) - Coordenação Técnica. (Relatório Técnico). 2007.

OGUCHI, Takashi. GIS applications in geomorphology - a review. VI Simpósio Nacional de Geomorfologia, 2006, Goiânia, GO. Anais... Goiânia: UBG, 2006. Lectures, p.10.

QUEIROS-FILHO, Alfredo Pereira de. A Escala nos Trabalhos de Campo e de Laboratório. In: VENTURI, Luis Antonio Bittar. (org) Praticando Geografia: técnicas de campo e laboratório. Oficina de Textos. São Paulo-SP, 2005

RAMOS, Verônica Moreira; GUIMARÃES, Renato Fontes; REDIVO, André Luciancencov; CARVALHO-JÚNIOR, Osmar Abílio de; FERNANDES, Nelson Ferreira e GOMES, Roberto Arnaldo Trancoso. Avaliação de Metodologias de Determinação do Cálculo de Áreas de Contribuição. Revista Brasileira de Geomorfologia. União da Geomorfologia Brasileira Ano 4, nº 2, UFU. Uberlândia - MG, 2003, 41-49 pp. ROSS, Jurandir Luciano Sanches. Geomorfologia: Ambiente e Planejamento. Sao Paulo: Contexto, 1990. 85p ROSS, Jurandir Luciano Sanches. Registro cartográfico dos fatos geomorfológicos e a questão da taxonomia do relevo. Revista do Departamento de Geografia. 17-29 pp. São Paulo, IG-USP, 1992.

ROSS, Jurandyr Luciano Sanches. Análise Empírica da Fragilidade dos Ambientes Naturais e Antropizados. Revista do Departamento de Geografia n 8, 63-74 pp. DG-FFLCH-USP, São Paulo, 1994.

ROSS, Jurandyr Luciano Sanches. Análise e Síntese na Abordagem Geográfica da Pesquisa para o Planejamento Ambiental. Revista do Departamento de Geografia. 9. 165-175 pp. DG-FFLCH-USP, São Paulo, 1995 ROSS, Jurandir Luciano Sanches. Ecogeografia do Brasil: Subsídios para planejamento ambiental. $1^{\text {a }}$ ed. Editora Oficina de Textos, São Paulo 2006.

SEI - SUPERITENDENCIA DE ESTUDOS ECONOMICOS E SOCIAIS DA ESTADO DA BAHIA. Balanco hídrico do Estado da Bahia. Salvador: SEI, 1999. 249p (Serie Estudos e Pesquisas v 45)

SEI - SUPERITENDENCIA DE ESTUDOS ECONOMICOS E SOCIAIS DA ESTADO DA BAHIA. Base Planimetrica do Estado da Bahia. Salvador: SEI, V. 1: 1 CD-ROM 2001

SEI - Superintendência de Estudos e Informações. BASE cartográfica digital. Estado da Bahia Mapeamento topográfico sistemático 1:100.000. Salvador: SEI, 2001b-. 2 CDROM

SHUTTLE SRTM-NASA (2001) JPL (2004). Jet Propulsion Laboratory - Shuttle Radar Topography Mission. Site:http://www2.jpl.nasa.gov/srtm/dataprod.htm. Acesso: 12/02/2006.

SILVA, Ardemirio de Barros. Sistemas de informações geo-referenciadas conceitos e fundamentos. São Paulo, SP: Universidade de Campinas, 2003. 236 p.

SPÖRL, Cristiane. Análise da Fragilidade Ambiental Relevo-Solo com Aplicação de Três Modelos Alternativos nas Altas Bacias do Rio Jaguari-Mirim, Ribeirão do Quartel e Ribeirão da Prata. 2001. Dissertação (Mestrado) Programa de Pos Graduação em Geografia- FFLCH - USP, São Paulo.

TRICART, Jean. Principes et méthodes de geomorphologie. Paris: Masson Ed., 1965, 201p

VALERIANO, Márcio de Morisson; MORAES, Jener Fernando Leite de. Extração de rede de drenagens e divisores por processamento digital de dados topográficos. Anais do VIII SBSR- Simpósio Brasileiro de Sensoriamento Remoto, Salvador-BA, Brasil abril de 1996, INPE- Instituto de Pesquisas Espaciais, 1996

VALERIANO, Márcio de Morisson. Modelos digitais de elevação de microbacias elaborados com krigagem. São José dos Campos: INPE: Coordenação de Ensino, Documentação e Programas Especiais (INPE-9364-RPQ/736). 54p. 2002.

VALERIANO, Márcio de Morisson; CARVALHO-JÚNIOR, O. A. Geoprocessamento de modelos digitais de elevação para mapeamento da curvatura horizontal em microbacias. Revista Brasileira de Geomorfologia, v.4, n.1, p.17-29, 2003

VALERIANO, Márcio de Morisson. Curvatura vertical de vertentes em microbacias pela análise de modelos digitais de elevação. Revista Brasileira de Engenharia Agrícola e Ambiental, v.7, n.3, p.539-546, 2003.

Mercator - volume 9, número 20, 2010: set./dez. 
VALERIANO, Márcio de Morisson. Mapeamento da declividade em microbacias com sistemas de informaçãogeográfica. Revista Brasileira de Engenharia Agrícola e Ambiental, v.7, n.2, p.303-310, 2003 b.

VALERIANO, Márcio de Morisson. Modelos Digitais de Elevação com dados SRTM disponíveis para a América do Sul. INPE, São José dos Campos, 2004.

VALERIANO, Márcio de Morisson. Visualização de imagens topográficas. Anais do XIII SBSR - Simpósio Brasileiro de Sensoriamento Remoto, Florianópolis-SC, Brasil 21-26 abril de 2007, INPE - Instituto de Pesquisas Espaciais, p. 1377-1384.

Trabalho enviado em setembro de 2010

Trabalho aceito em dezembro de 2010 